\title{
Dissecting Between-Plant and Within-Plant Wage Dispersion: Evidence from Germany
}

\author{
DANIEL BAUMGARTEN (iD, GABRIEL FELBERMAYR (iD) and \\ SYBILLE LEHWALD
}

\begin{abstract}
Using rich linked employer-employee data for (West) Germany between 1996 and 2014, we conduct a decomposition analysis based on recentered influence function (RIF) regressions to analyze the relative contributions of various plant and worker characteristics to the rise in German wage dispersion. Moreover, we separately investigate the sources of between-plant and within-plant wage dispersion. We find that industry effects and the collective bargaining regime contribute the most to rising wage inequality. In the case of collective bargaining, both the decline in collective bargaining coverage and the increase in wage dispersion among the group of covered plants have played important roles.
\end{abstract}

\section{Introduction}

Wage inequality has been on the rise in most (industrialized) countries in the last few decades (Acemoglu and Autor 2011). Recent research has pointed to the growing importance of workplace heterogeneity for this development: a large fraction of the increase in overall wage inequality is due to increased wage dispersion between as opposed to within firms or plants. While this trend

JEL codes: J31, J51, C21, F16.

*The authors' affiliations are, respectively, LMU Munich, CESifo, RWI, Munich, Germany. E-mail: daniel.baumgarten@econ.lmu.de; Kiel Institute for the World Economy, Kiel University, Kiel, Germany. Email: felbermayr@ifw-kiel.de; Federal Ministry for Economic Affairs and Energy, Berlin, Germany. E-mail: sybille.lehwald@bmwi.bund.de. The authors are very thankful to the editor, Chris Riddell, and an anonymous referee for very helpful comments. Furthermore, they thank Thomas Lemieux, Bernd Fitzenberger, Steffen Mueller, Jakob Munch, Mette Foged, Monika Schnitzer, Anna Gumpert, Martin Watzinger, as well as participants at the IO and trade seminar at the LMU, the EDGE Jamboree in Copenhagen, DICE Duesseldorf, and the Workshop International Economics in Goettingen for valuable comments and discussion. They further thank the Research Data Center of the German Federal Employment Agency at the Institute for Employment Research (IAB) for their great support with accessing the data. All remaining errors are their own. This research project originally builds on a study on behalf of the Bertelsmann Foundation and was further developed with financial support from Deutsche Forschungsgemeinschaft through CRC TRR 190. The authors thank these institutions for their support. The views expressed are the authors' and should not be interpreted as representing the views of the Federal Ministry for Economic Affairs and Energy.

Industrial Relations, DOI: 10.1111/irel.12249. Vol. 59, No. 1 (January 2020). 2020 The Authors.

Industrial Relations published by Wiley Periodicals, Inc. on behalf of Regents of the University of California (RUC)., Inc., 350 Main Street, Malden, MA 02148, USA, and 9600 Garsington Road, Oxford, OX4 2DQ, UK.

This is an open access article under the terms of the Creative Commons Attribution License, which permits use, distribution and reproduction in any medium, provided the original work is properly cited. 
is shared by many countries, the specific factors explaining this increase are still underexplored. ${ }^{1}$

Against this background, the aim of this article is to pin down the role of central plant and worker characteristics for the increase in wage inequality, focusing on (West) Germany. For this purpose, we use detailed linked employeremployee data, covering the years 1996 to 2014. We adopt a particularly rich framework and jointly evaluate the contributions of standard worker characteristics (education, age, tenure, occupation, and nationality) and an extensive set of plant characteristics (plant size, export status, collective bargaining coverage, existence of a works council, technological status, investment intensity, industry, and region). As the central contribution of our analysis, we separately analyze the sources of changes in between-plant and within-plant wage dispersion, thus shedding light on the (possibly divergent) drivers of these two important subcomponents of wage inequality and informing theoretical analyses. ${ }^{2}$ In doing so, we also provide updated evidence on differences in the sources of upper-tail and lower-tail (between-plant) wage dispersion. Finally, we analyze the sources of the recent slowdown in German wage inequality (cf. Möller 2016) and compare the results for West Germany to the ones for East Germany.

Disentangling the role of each single variable for the rise in wage dispersion, conditional on other variables, is politically relevant. For instance, an increase in overall inequality due to aging of the workforce is valued differently than a similar increase driven by a higher wage gap between skill groups. However, quantifying the relative contributions of various factors to rising inequality in a unified framework, both through compositional changes and changes in the conditional wage structure, is an empirical challenge. To this end, we apply a state-of-the-art decomposition method based on recentered influence function (RIF) regressions (Firpo, Fortin, and Lemieux 2009). Crucially, compared to sequential decompositions, this approach has the further advantage of being path independent.

Our main findings are as follows. First, we confirm that wage dispersion among full-time male workers in Germany has risen strongly and fairly

\footnotetext{
${ }^{1}$ Davis and Haltiwanger (1991), Dunne et al. (2004), and more recently, Barth et al. (2016), Handwerker and Spletzer (2016), and Song et al. (2019) provide evidence for the United States; Faggio, Salvanes, and Van Reenen (2010) and Mueller, Ouimet, and Simintzi (2017) for the UK; Card, Heining, and Kline (2013) for Germany; and Helpman et al. (2017) for Brazil. In contrast, there are mixed results regarding the importance of the between-firm component in Sweden (Akerman et al. 2013; Håkanson, Lindqvist, and Vlachos 2015).

${ }^{2}$ Note that even a (hypothetically) important contribution of plant-level characteristics to overall wage inequality does not necessarily imply that these factors are also the sources of increased between-plant wage dispersion. Instead, they could also be associated with higher within-plant wage inequality. By the same token, individual-level characteristics (and the returns to them) could well be responsible for increased between-plant wage dispersion, e.g., through increased sorting.
} 
continuously between 1996 and 2010, but slightly declined thereafter. Both the strong increase and the subsequent slight decrease were driven by the between-plant as opposed to the within-plant component of wage dispersion.

Second, two employer-level characteristics contributed the most to increasing wage dispersion: industry effects and the collective bargaining regime. The former matters in terms of the wage structure effect while, in the case of collective bargaining, both the composition and the wage structure play a substantial role. The former reflects the strong decline in collective bargaining coverage and the latter is due to both an increase in the wage gap between covered and uncovered plants and a strong increase in wage dispersion within the group of covered plants. According to the point estimates of the decomposition results, the effects associated with the industry and the collective bargaining regime together account for more than 100 percent of the total increase in the log wage variance between 1996 and 2010, where one has to take into account that several other factors are associated with declining wage dispersion. Both industry effects and collective bargaining have contributed to rising wage dispersion in very specific ways. They are sources of increasing between-plant wage dispersion, but they are, if at all, negatively related to within-plant wage inequality. Moreover, they have affected lower-tail as opposed to upper-tail (between-plant) wage inequality.

Third, in terms of individual-level characteristics, education is the characteristic that matters the most where both employment shifts toward more highly skilled workers and, even more so, changes in the skill-related wage structure, particularly in the wage gap between highly educated and less educated workers, have played important roles. These factors contributed to both within-plant and between-plant wage dispersion. Interestingly, we find that the skill-related wage structure effect, in particular, is quantitatively even more important for between-plant than for withinplant wage inequality, reflecting that a major part of changes in the skill-wage gaps has arisen from increasing between-plant wage differentials. We attribute this finding to increased assortative matching along the skill dimension.

Fourth, just as interesting as the factors that have contributed the most to rising wage dispersion are the ones that have not. Plant size, exporting status, plant technology, and investment per worker are all of little if any quantitative importance for the increase in wage dispersion. This is remarkable given that many potential culprits for the increase in wage inequality such as the rise of superstar firms, globalization, and technological change could be expected to materialize (at least partly) via these channels. It also underscores that simple, monocausal explanations for the rise in wage dispersion do not exist and that the impact of drivers such as international trade may be having indirect (e.g., by affecting institutions) rather than direct effects. 
This article builds on and contributes to a rich existing literature on wage inequality. First, our findings relate to recent research that puts special emphasis on the firm or plant component of wage dispersion. Most notably, Card, Heining, and Kline (2013) use (West) German linked employer-employee data and document that about 60 percent of the increase in cross-sectional wage dispersion is due to plant (fixed) effects and the covariance between plant and person effects. Their analysis rests on the estimation approach with additive person and plant fixed effects, pioneered by Abowd, Kramarz, and Margolis (1999). Card, Heining, and Kline (2013) did not explore, however, which specific factors, i.e., plant and worker characteristics, account for the growing importance of plant-level pay. They provide tentative evidence that the decline in collective bargaining has likely contributed to this development, yet they do not explore the quantitative importance of this channel. ${ }^{3}$ Other research has focused on selected alternative (potential) drivers. ${ }^{4}$ Goldschmidt and Schmieder (2017) analyzed the importance of domestic (on-site) outsourcing of food, cleaning, security, and logistics services and found that this channel can account for approximately 9 percent of the increase in German wage inequality since the 1980s. Turning to international evidence, Handwerker and Spletzer (2016), having in mind a similar hypothesis as Goldschmidt and Schmieder (2017), analyzed whether an increasing concentration of occupations at establishments has played a role. They found that this channel can only account for a small amount of the increase in (between-establishment) wage dispersion in the United States. Song et al. (2019), on the other hand, provided evidence that the increase in between-firm inequality in the United States has been driven by both increased sorting of highwage workers into high-wage firms and increased employee segregation in terms of the worker-fixed pay component, where higher paid and lower paid employees are increasingly clustering in different firms. Other firm or plant characteristics that have been found to be relevant are the industry of the workplace (Barth et al. 2016) and the export status of the plant (Baumgarten 2013; Egger, Egger, and Kreickemeier 2013; Helpman et al. 2017). ${ }^{5}$

\footnotetext{
${ }^{3}$ Hirsch and Müller (2018) provide further evidence in this respect. They showed that, in the cross-section, establishment wage premia are indeed larger on average but less dispersed among plants covered by a collective agreement than among uncovered ones. Yet they did not explicitly analyze the role of the decline in collective bargaining for changes in (between-plant) wage dispersion over time.

${ }^{4}$ See Card et al. (2018) for a summary of a rich literature on the determinants of firm-level pay, without, however, focusing on drivers of changes in these premia over time.

${ }^{5}$ The focus on the export status is motivated by recent trade theories, which analyze the link between international trade and wage inequality in a setting with heterogeneous firms and labor-market imperfections (e.g. Egger and Kreickemeier 2012; Felbermayr, Impullitti, and Prat 2018; Helpman, Itskhoki, and Redding 2010). In these models, the exporter wage premium, the wage differential between workers employed at exporters and the ones employed at nonexporters, is the key transmission channel from trade to wage inequality.
} 
Compared to these studies, we adopt a more agnostic, but also more comprehensive, approach. Instead of pursuing one specific hypothesis, we account for a whole set of explanatory factors and quantify their respective contributions to the increase in overall as well as in between-plant and within-plant wage dispersion. Thus, our analysis can be seen as an attempt to open the black box of those plant (and worker) effects highlighted in Card, Heining, and Kline (2013) and the following literature. While our decomposition analysis does not enable us to identify causal effects in a deeper, structural sense, we are able to identify the proximate sources of increased wage dispersion that any meaningful structural explanation should be consistent with.

Second, our findings relate to the more specific literature on the sources of increasing wage dispersion in Germany. Indeed, Germany is an interesting case in point, as it has long been known for a rather stable wage distribution, but in the last few decades experienced a strong increase in wage inequality (which seems to have slowed down or even slightly reversed after 2010, see Möller 2016). In fact, the German wage structure shares many of the developments observed in the United States (Dustmann, Ludsteck, and Schönberg 2009), although there also some notable differences. First, inequality at the bottom of the wage distribution started to rise only in the 1990s, one decade later than in the United States (Dustmann, Ludsteck, and Schönberg 2009). Also, evidence points toward a more uniform increase in wage dispersion along the entire distribution in more recent years (Biewen and Seckler 2019), whereas wages have been polarizing in the United States (Autor, Katz, and Kearney 2008). Previous research has already hinted at some important sources of rising (West) German wage inequality. In their seminal contribution, Dustmann, Ludsteck, and Schönberg (2009) stress the importance of changes in workforce composition (in line with Lemieux 2006) and the decline in collective bargaining. ${ }^{6}$ In addition, they provide indicative evidence that technological change has played a role for the widening of the wage distribution at the top. In line with most earlier studies, Dustmann, Ludsteck, and Schönberg (2009) mostly rely on plain individual-level data, the bargaining status of the plant being the only plant-level characteristic considered. Building upon these results, first Antonczyk, Fitzenberger, and Sommerfeld (2010) and, more recently, Biewen and Seckler (2019), have conducted decomposition analyses of the increase in German

\footnotetext{
${ }^{6}$ In subsequent research, Dustmann et al. (2014) also pointed to greater wage flexibility within the covered sector, which they attributed to an increased use of "opening clauses" in industry-level collective agreements.
} 


\section{0 / Daniel Baumgarten, Gabriel Felbermayr, and Sybille Lehwald}

wage dispersion using linked employer-employee data ${ }^{7}$ and accounting for several worker and firm characteristics. Biewen and Seckler (2019) attribute the largest part of the observed increase in wage inequality to compositional changes in terms of collective bargaining coverage and personal characteristics such as workers' age and education. While both Antonczyk, Fitzenberger, and Sommerfeld (2010) and, in particular, Biewen and Seckler (2019), are similar in spirit to our analysis, we expand on them in several respects. First, we explicitly distinguish betweenplant and within-plant wage dispersion. Second, the LIAB data employed in our analysis is richer in terms of plant-level variables than the alternative GSES data used by Biewen and Seckler (2019) and allows us to account for characteristics such as the export status, the technology status, investment intensity, and the existence of a works council. ${ }^{8}$ Finally, we also analyze the recent decline in German wage dispersion after 2010 and compare the experiences in West and East Germany to each other. ${ }^{9}$

The remainder of the article is organized as follows. In the next section, we describe the linked employer-employee data used for our analysis. Then, we briefly discuss the key developments in the German wage structure. We follow that with a section explaining the decomposition analysis. We then present a first descriptive overview of changes in the composition of workers and plants as well as changes in the wage structure associated with worker and plant characteristics, the ingredients to our decomposition analysis. In the penultimate section, we provide a detailed discussion of our decomposition results, followed by a final concluding section.

\footnotetext{
${ }^{7}$ Both Antonczyk, Fitzenberger, and Sommerfeld (2010) and Biewen and Seckler (2019) relied on the German Structure of Earnings Surveys (GSES) provided by the German Federal Statistical Office, while our analysis is based on the LIAB data provided by the Institute for Employment Research (IAB). The latter was also used in, e.g., Dustmann, Ludsteck, and Schönberg (2009) and is based on the same underlying social security records as the paper by Card, Heining, and Kline (2013). Both data sets have their pros and cons. In contrast to the LIAB data, the GSES wage information is not top-coded at the social security contribution ceiling and is a measure of hourly (rather than daily) wages. On the other hand, the LIAB is based on administrative data, is richer in terms of plant-level variables, covers more sectors, and is available at annual frequency (as opposed to every approximately 5 years). See Biewen and Seckler (2019) for a more detailed discussion.

${ }^{8}$ Biewen and Seckler (2019) used the LIAB data to impute the export behavior of firms in the GSES data.

${ }^{9}$ Other recent papers have analyzed additional aspects of the observed changes in the German earnings distribution. Biewen, Fitzenberger, and de Lazzer (2018) analyzed the role of employment interruptions and temporary part-time work for wage inequality of full-time workers. Biewen and Plötze (2019) studied the role of changes in working hours for the change in monthly earnings inequality. While important, the focus of these papers is somewhat orthogonal to our analysis, as they are not (primarily) concerned with the plantlevel dimension of wage inequality.
} 


\section{Data and Sample Restrictions}

We base our analysis on the German LIAB data, which is a linked employer-employee data set provided by the Institute for Employment Research (IAB) in Nuremberg. ${ }^{10}$ It combines the IAB Establishment Panel with social security data on all workers who were employed in one of the establishments as of June 30 in any given year.

The IAB Establishment Panel is a stratified sample of all establishments that employ at least one worker subject to social security. The strata variables are defined over regions, industries, and size classes. Appropriate weights, which are inverse to the sampling probability, are provided to ensure the representativeness of the results. The IAB Establishment Panel started in 1993 with West German plants, while East German plants have been included from 1996 onward. Although participation in the IAB Establishment Panel is voluntary, the response rate is very high (up to 80 percent for repeatedly interviewed establishments). The survey is very detailed and covers many different topics. Further plant-level variables such as the industry affiliation and the region where the plant is located are provided by the Establishment History Panel.

The employee data are based on social security notifications made by the employer on behalf of their employees, which are mandated by law. Hence, only workers covered by social security are included in these employment statistics, while civil servants and the self-employed are not. The data still cover, however, about 80 percent of the German workforce. These compulsory social security records contain personal information such as gender, year of birth, citizenship, level of education, occupation (at a three-digit level), and the top-coded daily wage. Specifically, wages are right-censored at the contribution ceiling to the social security system. In our sample, between 9 and 14 percent of the wage observations are censored in every year. To address this problem, we follow Dustmann, Ludsteck, and Schönberg (2009) and impute the missing upper tail of the wage distribution using a series of Tobit regressions. ${ }^{11}$ Using the estimated parameters from these models, we replace each censored wage value with a random draw from the upper tail of the appropriate conditional wage distribution. Wages are then converted into constant year 2000 euros by deflating them with the Consumer Price Index as provided by the German Federal Statistical Office.

\footnotetext{
${ }^{10}$ More precisely, this study uses the Linked-Employer-Employee Data (LIAB;cross-sectional model 2 1993-2014 [LIAB QM2 9314]) from the IAB. Data access was provided via on-site use at the Research Data Centre (FDZ) of the German Federal Employment Agency (BA) at the IAB and subsequently remote data access. See Klosterhuber, Lehnert, and Seth (2016) for a detailed description of the data.

${ }^{11} \mathrm{We}$ run a series of Tobit regressions for each year, education group, and region (east/west). The explanatory variables are the ones that we also use in our decomposition analysis described below.
} 


\section{2 / Daniel Baumgarten, Gabriel Felbermayr, and Sybille Lehwald}

Similar to previous research (e.g., Dustmann, Ludsteck, and Schönberg 2009; Card, Heining, and Kline 2013), we limit our attention to full-time jobs held by men in the age range 18 to 65 . We exclude marginal jobs that are subject to reduced social security contributions as well as workers that undergo training. For workers who hold multiple jobs, we only keep the highest-paying one. We exclude observations that are reported to have an (implausibly) low daily wage of less than ten euros. To be comparable to the earlier research cited above, and because West and East Germany are still characterized by substantially different labor markets and wage schedules, we focus on West Germany for the main part of our analysis. ${ }^{12}$ Our period of analysis covers the years from 1996 to 2014. However, for the most part, we focus on the period 1996-2010, which was characterized by a fairly steady rise in wage dispersion (as we show in the next section). In an extension, we also look at the more recent period from 2010 to 2014. Not only was this second (shorter) period characterized by a decline in wage dispersion, but also by some changes to the variables in the data set, which makes the separation of these two time periods - in our view - a reasonable choice. Taking these restrictions into account, we end up with 964,587 (614,483) workers and 3433 (6571) plants in 1996 (2010). It is worth noting that our sample restrictions, in particular due to the focus on full-time workers, may lead to an underestimation of the overall level and growth of wage inequality among German male workers. However, as the data do not contain information on the hours worked, including part-time workers would add too much noise to the analysis.

\section{Trends in German Wage Inequality}

Panel (a) of Figure 1 displays the evolution of overall wage inequality for our sample as measured by the variance of log real wages. It can be seen that wage dispersion has been rising fairly steadily (except for a dip in 2002) up to 2010 before declining slightly in the following three years and mildly rebounding in 2014. In terms of magnitude, the increase between 1996 and 2010 (2014) amounts to about 77 percent (65 percent) of the initial value, which is substantial.

The figure also shows the development of between-plant and within-plant wage dispersion. The variance has the attractive property that the between and the within component add up to the total, fulfilling the criterion of an

\footnotetext{
${ }^{12}$ Moreover, we do not consider those establishments in which the reporting unit in the Establishment Panel has changed over time. This is due to the fact that such a change in the reporting unit might not be accompanied by a corresponding change in the workforce data because the latter's establishment ID stays the same.
} 
FIGURE 1

Evolution of Wage Dispersion

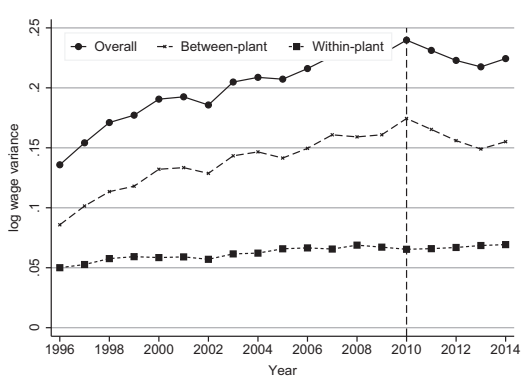

(a) Different inequality measures

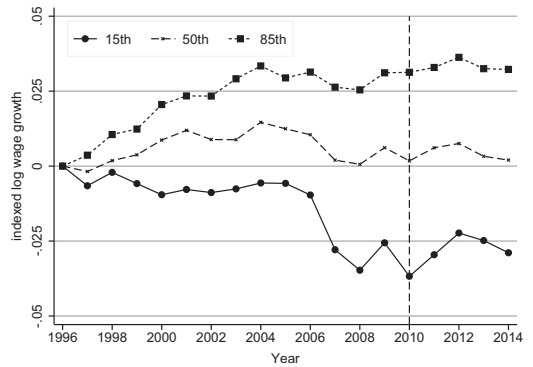

(b) Wage growth at percentiles

Notes: Panel (a) shows the evolution of the overall, between-plant, and within-plant wage variance. We construct the measure of between-plant (within-plant) variance by running yearspecific regressions of $\log$ real individual wages on a full set of plant fixed effects. We then take the variance of predicted (residual) wages as a measure of between-plant (within-plant) inequality. Panel (b) shows indexed $\log$ real wage growth at the 15th, 50th, and 85th percentiles. Because at most 14 percent of wage observations are censored in each year, the 85 th wage percentile is not affected. Both figures are based on LIAB data. The sample includes full-time male workers between 18 and 65 years of age who work in West Germany.

additively separable inequality measure (Shorrocks 1980). Technically, this can be formalized as follows:

$$
\frac{1}{N_{t}} \sum_{i}\left(w_{i t}-\bar{w}_{t}\right)^{2}=\frac{1}{N_{t}} \sum_{j} N_{j t}\left(\bar{w}_{j t}-\bar{w}_{t}\right)^{2}+\frac{1}{N_{t}} \sum_{j} \sum_{i \in j}\left(w_{i t}-\bar{w}_{j t}\right)^{2}
$$

where workers are indexed by $i$ and plants by $j . N_{t}$ and $N_{j t}$ denote the overall number of workers and the number or workers in plant $j$ at time $t$, respectively. In addition, $w_{i t}$ denotes the $\log$ wage of individual $i, \bar{w}_{j t}$ the mean $\log$ wage within plant $j$, and $\bar{w}_{t}$ the overall mean log wage at time $t$. The overall variance is given on the left-hand side, while the first term on the right-hand side denotes the between-plant variance and the second term on the right-hand side the within-plant variance.

While in 1996 the between-plant component already accounted for 63 percent of overall wage inequality, this share rose to 73 percent by 2010 . Thus, this component contributed 85 percent to the increase in wage inequality over the main period of analysis. This is in line with findings of the related literature, which also stresses the growing importance of between-plant wage dispersion. Interestingly, it is also the between-plant component that accounts for 


\section{4 / Daniel Baumgarten, Gabriel Felbermayr, and Sybille Lehwald}

the decline in wage dispersion after 2010, while within-plant wage dispersion continued to increase, albeit modestly.

While the variance is a good and frequently used summary measure of overall wage dispersion, it does not allow one to analyze changes at different parts of the wage distribution. Therefore, Panel (b) of Figure 1 shows changes in $\log$ real wages over time at different percentiles of the earnings distribution (normalized to the year 1996). Workers at the median and at the 85th percentile have realized real wage gains, while workers at the 15 th percentile have faced declines in real wages. The latter were particularly pronounced in the period 2006-2010, while they recovered slightly thereafter. ${ }^{13}$ Considering the 85-50 and 50-15 log wage differentials as measures of upper-tail and lowertail wage inequality, respectively, it becomes apparent that the larger part of the overall increase in wage inequality between 1996 and 2010 was due to changes in the lower part of the earnings distribution.

\section{Empirical Approach and Methodology}

In order to quantify the relative importance of (changes in) various covariates for (changes in) the distribution of wages, our empirical approach has to meet different requirements. First, it needs to allow us to "go beyond the mean." meaning that we need to decompose changes in the cross-sectional distribution of wages as opposed to changes in the average wage. Second, we need to account for several covariates jointly in a comprehensive framework. This is because we are interested in the conditional effects of our covariates and on the contribution of each covariate relative to the other included factors. Third, for each single covariate, we would like to distinguish a composition effect that is linked to changes in the distribution of this factor, and a wage structure effect that reflects changes in the conditional wage distribution over time. The latter two requirements are usually referred to as allowing for a detailed decomposition.

A decomposition method that can be applied beyond the mean and allows for a detailed decomposition with respect to each single covariate in a unified framework is the so-called RIF regression approach, which is based on RIF regressions and was introduced by Firpo, Fortin, and Lemieux (2009). A simple intuition for this methodology is that it can be regarded as a generalization of a standard Oaxaca-Blinder decomposition technique (Blinder 1973; Oaxaca 1973) from the mean to other distributional statistics. Apart from being

\footnotetext{
${ }^{13}$ Note that the subset of workers (and their characteristics) at each percentile might have changed over time.
} 
computationally relatively simple, a key advantage of the RIF regression approach is that the decomposition results are path independent. The latter property implies that we do not have to take a stand on the sequential ordering of covariates in the decomposition process, which generally matters with other decomposition approaches. ${ }^{14}$ In the following, we sketch the key technical details underlying our approach. ${ }^{15}$

As Fortin, Lemieux, and Firpo (2011: 76) write, “[a] RIF-regression (Firpo et al. 2009) is similar to a standard regression, except that the dependent variable, Y, is replaced by the (recentered) influence function of the statistic of interest." In nontechnical terms, the influence function represents the contribution of a given observation to the distributional statistic of interest, e.g., the variance or the Gini coefficient.

Assuming that the conditional expectation of $\operatorname{RIF}(y ; v)$-where $y$ denotes the observed wage and $v\left(F_{Y}\right)$ the distributional statistic - can be modeled as a linear function of the explanatory variables,

$$
E[R I F(y ; v) \mid X]=X \gamma+\varepsilon,
$$

the corresponding parameters $\gamma$ can be estimated by ordinary least squares (OLS). Applying this approach to quantiles, the RIF regression corresponds to an unconditional quantile regression, which allows one to estimate the marginal effect of any explanatory variable, say, the share of workers covered by collective bargaining, on the $\tau$ th quantile of the wage distribution. Different from a standard conditional quantile regression, which only captures withingroup (or residual) wage effects of the covariates, the unconditional quantile regression captures both within-group and between-group effects. For example, in the case of collective bargaining, the (typically negative) within-group effect on wage inequality stems from the fact that within the covered sector, wages (among comparable workers) tend to be more compressed than in the noncovered sector. On the other hand, the (typically positive) between-group effects result from covered workers usually earning a higher conditional mean wage than noncovered workers. As this example illustrates, the within-group and the between-group effects may go into different directions, and one or the other may dominate at different points of the wage distribution. The RIF coefficients as such, however, do not allow us to disentangle the within-group and the

\footnotetext{
${ }^{14}$ Alternative approaches that also allow for detailed decompositions generally do not share the property of path independence, often face nonmonotonicity problems, and are computationally more cumbersome (see e.g., Chernozhukov, Fernández-Val, and Melly 2013; DiNardo, Fortin, and Lemieux 1996; Melly 2005).

${ }^{15}$ This section is very much based on Firpo, Fortin, and Lemieux (2013) and Fortin, Lemieux, and Firpo (2011). We refer the interested reader to these original contributions for a more extensive description of the empirical approach.
} 
between-group component so that we will resort to auxiliary evidence in cases where this distinction is of interest.

Due to the linearization, it is straightforward to apply the standard BlinderOaxaca decomposition to the RIF regression. Thus, if one is interested in decomposing changes in the distributional parameter $v\left(F_{Y}\right)$ between two different time periods $(t=0$ and $t=1)$, the decomposition reads as

$$
\hat{\Delta}_{O}^{v}=\bar{X}_{1}\left(\hat{\gamma}_{1}^{v}-\hat{\gamma}_{0}^{v}\right)+\left(\bar{X}_{1}-\bar{X}_{0}\right) \hat{\gamma}_{0}^{v},
$$

where $\hat{\Delta}_{O}^{v}$ denotes the overall change in the statistic $v$. The first term on the right-hand side denotes the wage structure effect, $\hat{\Delta}_{S}^{v}$, which is obtained by holding the distribution of covariates constant and only modifying the conditional wage structure (represented by the RIF coefficients). The second term denotes the composition effect, $\hat{\Delta}_{X}^{v}$, which is obtained by holding the conditional wage structure (RIF coefficients) constant and varying the distribution of covariates according to the observed changes between $t=0$ and $t=1$.

As Fortin, Lemieux, and Firpo (2011) explain, there may be a bias in the decomposition because the linear specification used in the regression is only a local approximation that does not generally hold for larger changes in the covariates. In particular, the RIF coefficients might change if the distribution of the covariates changes even though the true wage structure remains the same. To circumvent this problem, Fortin, Lemieux, and Firpo (2011) propose to combine the RIF regressions with a reweighting approach, where the counterfactual $\hat{\gamma}_{01}^{v}$ coefficients are obtained from a RIF regression on the period 0 sample reweighted to mimic the period 1 sample (such that $\operatorname{plim}\left(\bar{X}_{01}\right)=\operatorname{plim}\left(\bar{X}_{1}\right)$ ). Taking this adjustment into account, the pure wage structure effect ${ }^{16}$ amounts to

$$
\bar{X}_{1}\left(\hat{\gamma}_{1}^{v}-\hat{\gamma}_{01}^{v}\right)
$$

and the pure composition effect ${ }^{17}$ to

$$
\left(\bar{X}_{01}-\bar{X}_{0}\right) \hat{\gamma}_{0}^{v}
$$

Just as in the standard Blinder-Oaxaca decomposition, it is possible to obtain the detailed elements of the wage structure and the composition effects attributable to different subsets of the vector of explanatory variables, $X$. However, in the case of the wage structure effect, the detailed elements are not

\footnotetext{
16 The "naive" wage structure effect can be divided into the pure wage structure effect and the reweighting error. See Fortin, Lemieux, and Firpo (2011) for details.

17 The "naive" composition effect can be divided into a pure composition effect and a component measuring the specification error. The specification error captures the difference between the composition effect estimated using a nonparametric reweighting approach and the linear approximation obtained using the RIF regression.
} 
unique and, for categorical variables, depend on the choice of the base category, which has to be taken into account when interpreting the results.

It is important to stress that the decomposition method, similar to alternative decomposition approaches used in the literature (e.g., DiNardo, Fortin, and Lemieux 1996; Fairlie 2005; Mata and Machado 2005), relies on the assumption of the invariance of the conditional distribution and therefore ignores general equilibrium effects. For our analysis this implies, e.g., that the collective bargaining wage premium is assumed to be independent of collective bargaining coverage. Moreover, the decomposition takes all covariates as exogenously given and not themselves determined by other factors that might also lead to higher wage inequality. This, however, implies that a causal interpretation of the estimated effects is not possible.

We use this approach to quantify the contributions of an extensive set of explanatory factors to changes in the wage distribution. These factors include the personal characteristics education (four categories); ${ }^{18}$ age (five categories); ${ }^{19}$ tenure (six categories); ${ }^{20}$ nationality (German versus non-German); and dummies for three types of occupations, which are characterized by predominantly manual, routine, and abstract tasks, respectively (similar to Acemoglu and Autor 2011). Moreover, we consider a large set of plant characteristics: size as measured by total employment (ten categories) ${ }^{21}$ the export status (three categories); ${ }^{22}$ a dummy variable that indicates whether the plant has a works council; two dummy variables capturing the bargaining regime of the plant (sector-level and firm-level agreement, respectively, where no collective bargaining agreement is the base category); two dummy variables that equal one if the plant has invested in information and communications technology (ICT) and if the (self-assessed) technology status of the plant is above average compared to other plants in the same industry, respectively; and categorical information on investment per worker (six categories). ${ }^{23} \mathrm{We}$ also include full sets of two-digit industry and federal state dummies to capture

18 (1) Low: no vocational training, no high school; (2) Medium: high school and/or vocational training; (3) High: university or technical college. The fourth category consists of observations with missing educational information.

${ }^{19}$ (1) 18-25 years; (2) 26-35 years; (3) 36-45 years; (4) 46-55 years; (5) 56-65 years.

20 (1) 0-2 years; (2) 2-4 years; (3) 4-8 years; (4) 8-16 years; (5) >16 years; (6) missing tenure. Excluding the missing category, these roughly constitute quintiles of the West German tenure distribution in 1996.

${ }^{21}$ (1) 1-4 employees; (2) 5-9 employees; (3) 10-19 employees; (4) 20-49 employees; (5) 50-99 employees; (6) 100-199 employees; (7) 200-499 employees; (8) 500-999 employees; (9) 1000-4999 employees; (10) $\geq 5000$ employees.

22 (1) Nonexporters; (2) exporters; (3) establishments with missing export information, which comprises a fairly large number of establishments in the service sector.

${ }^{23}$ Five categories refer to the quintiles of this variable as measured in the base year 1996, while the sixth category comprises establishments with missing information on investments. 


\section{8 / Daniel Baumgarten, Gabriel Felbermayr, and Sybille Lehwald}

sectoral and regional shifts during our period under study. ${ }^{24}$ Finally, in this framework the constant captures that portion of (the change in) wage dispersion that cannot be explained by observables and thus can be interpreted as (change in) residual inequality of the base group.

We apply the decomposition method to changes in overall wage distribution as well as to changes in between-plant and within-plant wage dispersion. As explained above, for the most part, we conduct the decomposition analysis for the period 1996-2010, but turn to the more recent period from 2010 to 2014 in an extension. Likewise, while the main analysis focuses on West Germany, we conduct the decomposition analysis for East Germany in a further extension. For statistical inference, we rely on a bootstrap (200 replications) of the whole decomposition. To account for the correlation of wages within plants, a block bootstrap procedure is applied in which all observations within a given plant are resampled. Finally, throughout the analysis, we use appropriate sampling weights to ensure the representativeness of the results.

\section{Preliminary Evidence on Changes in the Workforce Composition and the Wage Structure}

Before discussing the detailed decomposition results of changes in wage dispersion, we provide descriptive evidence on changes in the composition of workers and plants as well as changes in the wage structure related to worker and plant characteristics. These constitute the ingredients, albeit in an unconditional and simplified way, to our decomposition analysis where we quantify their respective contributions to the increase in wage inequality.

Changes in the composition of workers and plants. The first two columns of Table 1 illustrate the composition of workers according to various individual and plant characteristics for the years 1996 and 2010.

In terms of sociodemographic characteristics, there is a visible trend toward more highly skilled and, even more so, older workers and those with longer tenure. The share of workers with university education in our sample increased

\footnotetext{
${ }^{24}$ We choose our base category to be a medium-skilled worker, in the age range of $26-35$, with $0-$ 2 years of tenure at his current employer, with German nationality, employed in an occupation characterized by mainly routine tasks, employed at an establishment with 200-499 employees, which does not export, has no works council, is not covered by a collective bargaining agreement of any sort, has not invested in information and communication technology, does not have a high technology status, is in the bottom quintile of investment per worker, belongs to the construction sector, and is located in North Rhine-Westphalia. With very few exceptions (i.e., collective bargaining, works council, investment in ICT), where the "no" category seems to be the natural benchmark, these constitute the modal categories of the variables in 1996.
} 


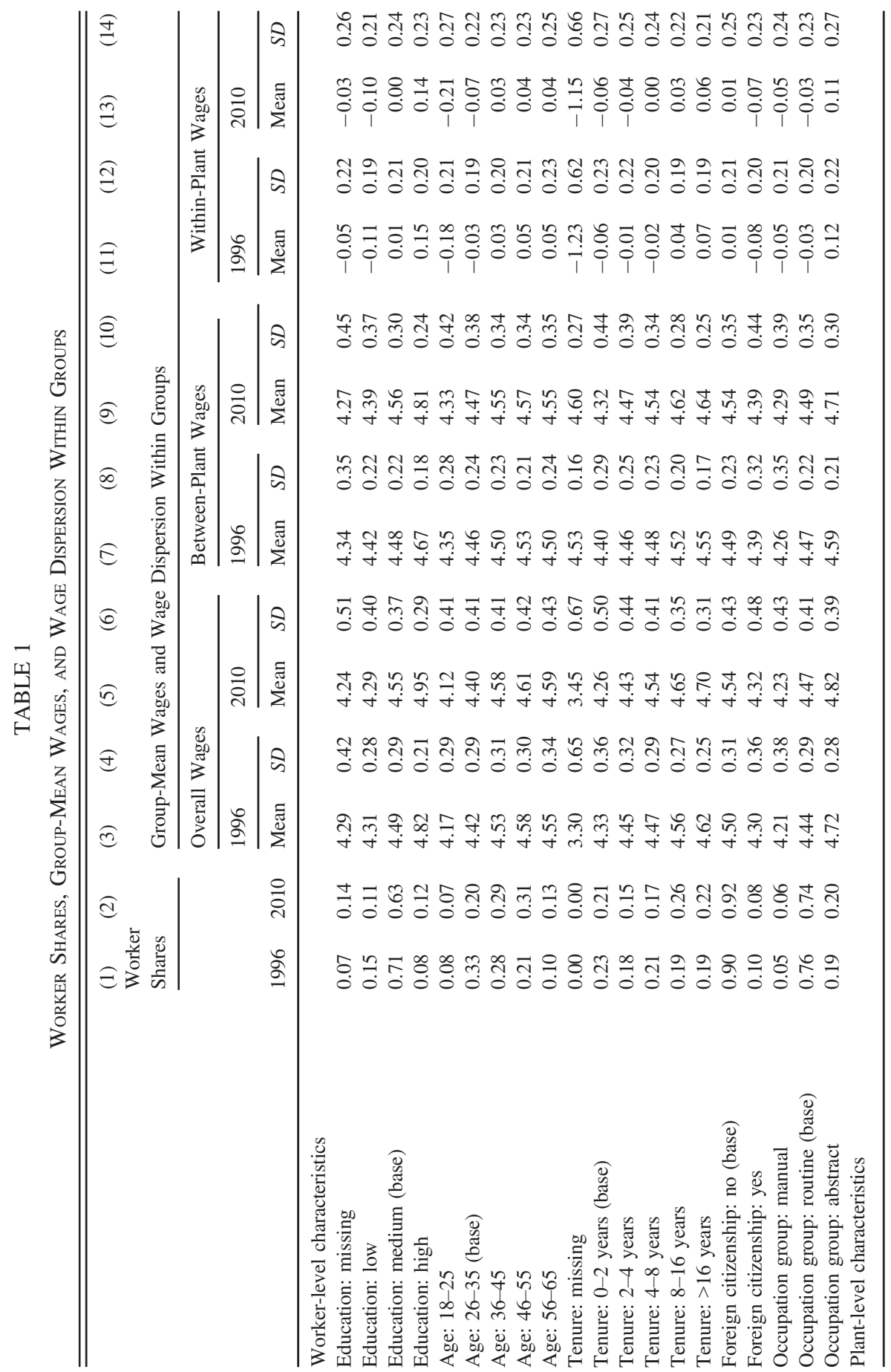


100 / Daniel Baumgarten, Gabriel Felbermayr, and Sybille Lehwald

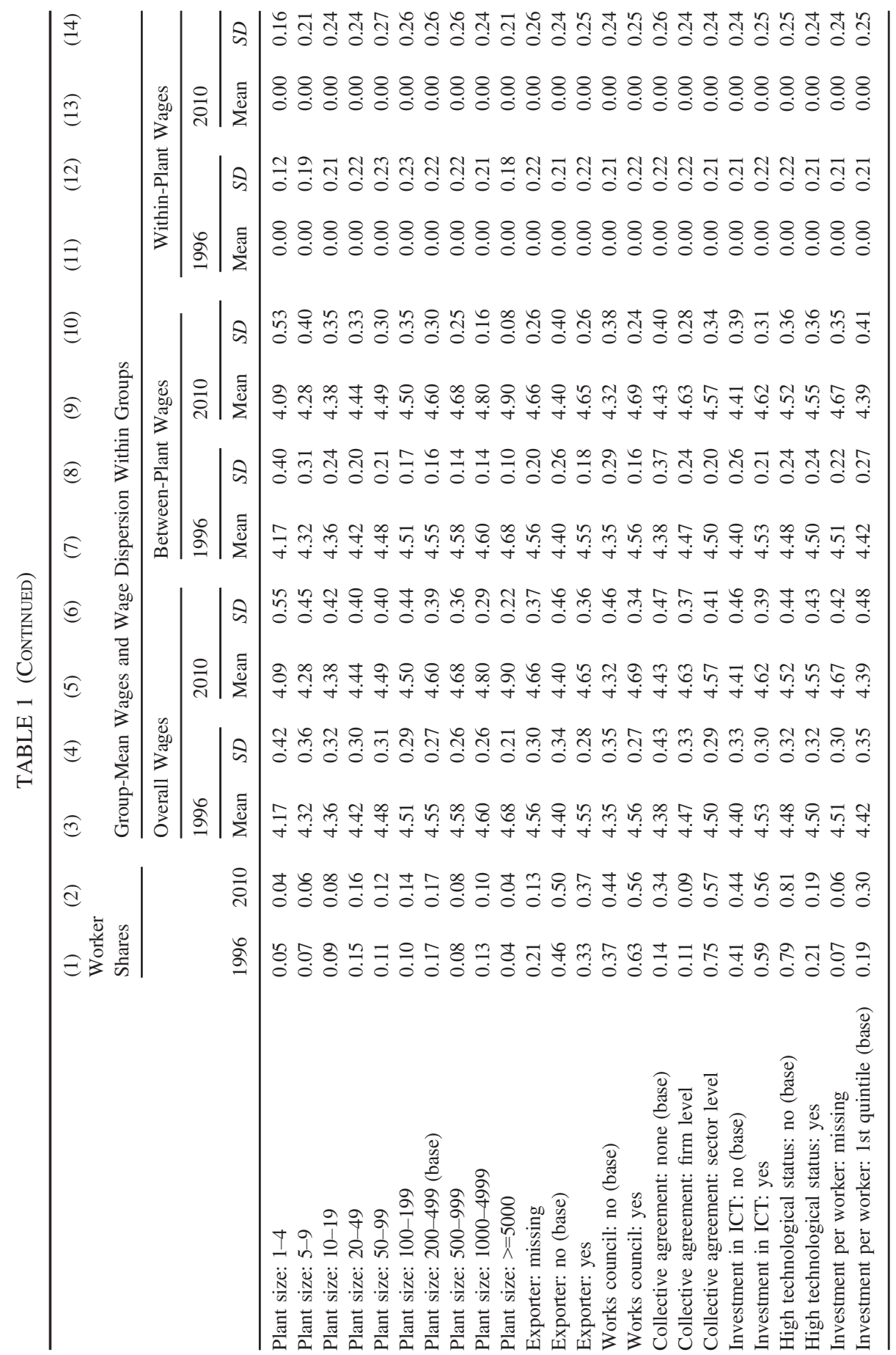


Between-Plant and Within-Plant Wage Dispersion / 101

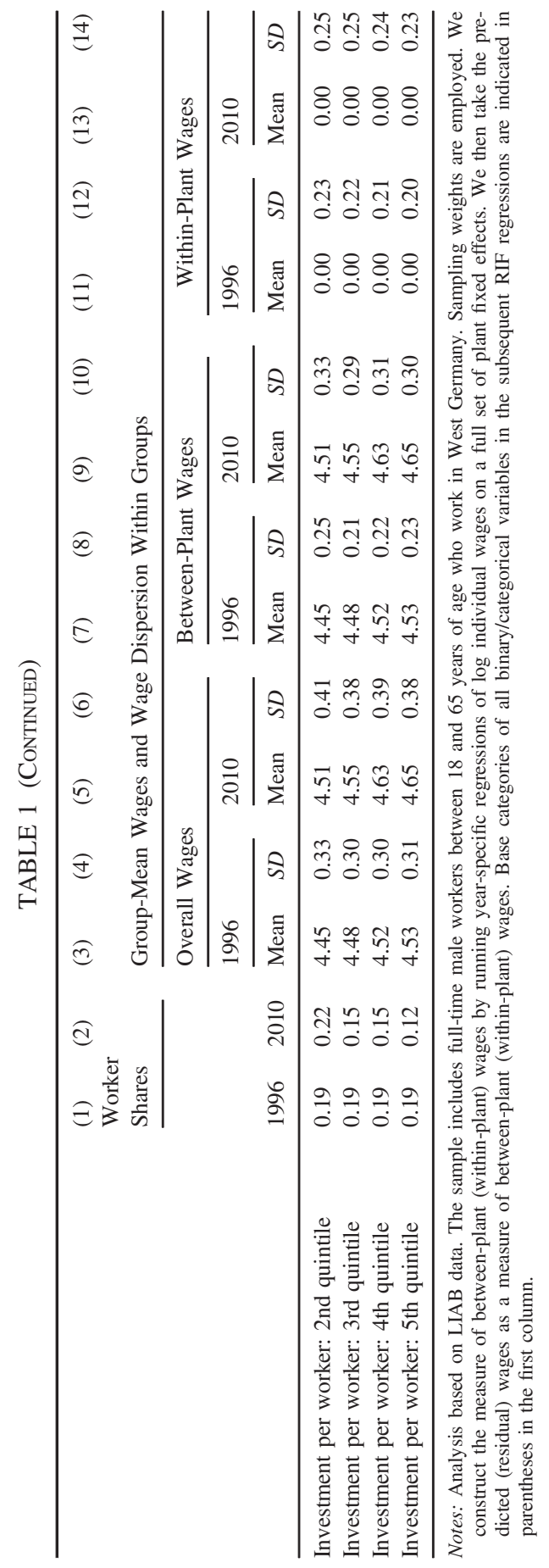


from 8 percent in 1996 to 12 percent in $2010 .^{25}$ In addition, the share of workers in the age group 46-55 (56-65) increased from 21 percent (10 percent) to 31 percent (13 percent), and the fraction of workers with more than 8 years of tenure rose from 38 to 48 percent. In contrast, there are small declines in the shares of routine workers and foreign workers, respectively. It has to be noted, however, that in the present data, workers are classified as foreigners/natives based on their nationality. Because the German nationality law was reformed during our sample period, making it easier to obtain German citizenship, this decline most likely reflects changes in citizenship rather than a decline in the number of migrant workers.

In terms of plant characteristics, the most drastic change relates to collective bargaining coverage. Table 1 shows that the share of workers covered by a sector-level bargaining agreement declined by 18 percentage points (from 75 percent to 57 percent), which was compounded by a small decrease in the share of workers covered by firm-level bargaining agreements (from 11 percent to 9 percent). ${ }^{26}$ Note that, because we are considering an unbalanced panel of plants, this decline comes about by both previously covered plants leaving collective bargaining and entering (young) plants being less likely to follow a collective agreement than exiting (old) ones. As a further change to the structure of industrial relations, the share of workers in plants with a works council also declined.

In addition, there has been a shift toward plants with less investment per worker. Finally, regarding the importance of international trade, no clear pattern emerges as both the share of workers at exporters and nonexporters increased in our sample, at the expense of plants with missing information on exports. Most likely, however, the group with missing information (which mostly are in the service sector) will predominantly consist of nonexporters.

Changes in the wage structure relating to worker and plant characteristics. The second part of Table 1 (columns 3-14) displays the structure and development of between-group mean wages and intra-group wage dispersion (as measured by the standard deviation), respectively, where these groups are

\footnotetext{
${ }^{25}$ In addition, the share of workers with missing education information also increased. According to their (unconditional) mean wages, this group seems to resemble most closely the group of low-skilled workers (which decreased by an amount similar to the increase of the missing data), suggesting that particularly the share of medium-skilled workers declined.

${ }^{26}$ In Germany, the recognition of trade unions regarding collective bargaining purposes is at the discretion of the firm. Once a firm has recognized a union, collective bargaining outcomes typically apply de facto to all workers in that firm, regardless of whether they are union members or not (for a discussion see e.g., Dustmann, Ludsteck, and Schömberg 2009 and Fitzenberger, Kohn, and Lembcke 2013). Such collective agreements are either formed at the firm or at the sector level. Firms that once have recognized a collective agreement, however, can later decide to opt out at their own discretion.
} 
again formed according to the same worker and plant characteristics. We present group-mean wages and intra-group wage dispersion for overall wages (columns 3-6) as well as separately for the between-plant (columns 7-10) and within-plant (columns 11-14) wage components. These subcomponents have been obtained as predicted values and residuals, respectively, of year-specific regressions of log real wages on a full set of plant fixed effects.

Intra-group wage dispersion. We first focus on the structure and development of intra-group wage dispersion, i.e., on the columns displaying the groupspecific standard deviations of wages, and start with overall wages (columns 4 and 6). In this respect, the table portrays two main findings. First, intra-group wage dispersion differs markedly across groups. For example, regarding individual characteristics, it slightly increases in the workers' age, and it is larger for foreigners than for natives. Surprisingly, it seems to decline rather quickly with higher education and with longer tenure. With respect to plant characteristics, it is, not surprisingly, substantially larger among plants not covered by collective bargaining agreements and among plants without a works council. It is also larger among smaller plants and nonexporters than among their respective counterparts.

Thus, several of the important compositional changes outlined in the previous subsection, in particular those regarding age, collective bargaining coverage, and the existence of a works council, entail a relative shift toward groups with larger within-group wage dispersion, suggesting that composition effects should play a role for the increase in wage inequality.

Second, in all groups, with no single exception, intra-group wage dispersion increased markedly over the period of analysis. Thus, in addition to composition effects, wage structure effects have also played a role. The magnitude of this increase again differs across groups, sometimes reinforcing initial differences in intra-group wage dispersion (e.g., in the case of plant size where it increased more among small than among large plants) and sometimes dampening them (e.g., in the case of collective bargaining for which intra-group wage dispersion increased more among covered than among uncovered plants).

Focusing on the structure and development of between-plant (columns 8 and 10) and within-plant (columns 12 and 14) wage dispersion, the betweenplant component is larger than the within-plant component for most subgroups. ${ }^{27}$ However, there are some differences. For example, among workers

\footnotetext{
${ }^{27}$ Note, however, that between-plant and within-plant wage dispersion, as measured by the variance, do not have to add up to the total for every single subgroup as they are still based on the plant-mean wages and within-plant wage residuals that we calculated for the entire sample. The covariance between these two terms will be zero if subgroups are formed according to plant-level characteristics - in which the mean within-group wage residual is always zero by construction-but will generally not be equal to zero if subgroups are formed according to individual characteristics.
} 


\section{4 / Daniel Baumgarten, Gabriel Felbermayr, and Sybille Lehwald}

employed at larger plants, the within component is more important. The same goes for workers employed at plants with a works council. In addition, the between-plant component has grown more strongly over time for most subgroups.

Mean wage gaps between groups. The overall wage structure is not only shaped by wage dispersion within groups but also by (mean) wage gaps between groups. Note that these mean differences matter for both the composition effect and the wage structure effect of the decomposition analysis. To the extent that between-group wage differentials change, they will contribute to the wage structure effect. On the other hand, to the extent that there are compositional shifts toward groups whose (initial) group-mean wages are relatively far from (close to) the grand mean, these will contribute to greater (lower) wage inequality via the composition effect.

Hence, Table 1 also shows mean wages by subgroups (e.g., columns 3 and 5 with respect to overall wages). At the individual level, we can observe a strong increase in the wage gap between the highly educated and those with lower levels of education and in the "returns" to an occupation characterized by abstract tasks relative to routine and manual tasks. There is also a growing wage penalty for younger age groups and for workers with shorter tenure. In addition, wage differences increased along a number of plant characteristics, such as plant size, exporting, the existence of a works council, and investment in ICT.

Again, we also show separately the structure and development of betweenplant and within-plant mean wages (columns 7 and 9 as well as 11 and 13, respectively). ${ }^{28}$ Interestingly, we see that, in the education, occupation, and tenure dimensions, most of the increase in the between-group wage gaps are due to the between-plant component. This finding provides tentative evidence that sorting in these dimensions has become more important over time.

\section{Decomposition Results}

We now turn to our detailed decomposition results based on RIF regressions. Our main specification generally refers to West Germany and focuses on the change in wage inequality between 1996 and 2010. We first discuss our findings regarding overall wage inequality. We then turn to our separate

\footnotetext{
${ }^{28}$ Due to the aforementioned reason that mean within-plant wage residuals are zero by construction at the plant level, this distinction is only interesting for groupings defined according to individual-level as opposed to plant-level characteristics.
} 
TABLE 2

Decomposition of Changes in the Overall Variance, 1996-2010

\begin{tabular}{|c|c|c|}
\hline \multirow[b]{3}{*}{ Total Change } & \multicolumn{2}{|l|}{$8.68 * * *$} \\
\hline & \multicolumn{2}{|l|}{$[0.47]$} \\
\hline & Composition & Wage Structure \\
\hline Nationality & $\begin{array}{c}-0.05^{* *} \\
{[0.02]}\end{array}$ & $\begin{array}{c}0.09 \\
{[0.15]}\end{array}$ \\
\hline Education & $\begin{array}{l}0.73 * * * \\
{[0.20]}\end{array}$ & $\begin{array}{l}1.92 * * * \\
{[0.34]}\end{array}$ \\
\hline Age & $\begin{array}{l}0.29 * * * \\
{[0.08]}\end{array}$ & $\begin{array}{l}2.23 * * * \\
{[0.67]}\end{array}$ \\
\hline Tenure & $\begin{array}{c}0.10 \\
{[0.08]}\end{array}$ & $\begin{array}{c}-3.36^{* * *} \\
{[1.09]}\end{array}$ \\
\hline Occupation & $\begin{array}{l}0.17 * * * \\
{[0.06]}\end{array}$ & $\begin{array}{c}0.61 * * \\
{[0.29]}\end{array}$ \\
\hline Region & $\begin{array}{c}-0.04 \\
{[0.07]}\end{array}$ & $\begin{array}{c}1.20 \\
{[0.90]}\end{array}$ \\
\hline Industry & $\begin{array}{c}0.14 \\
{[0.27]}\end{array}$ & $\begin{array}{l}4.04 * * * \\
{[1.55]}\end{array}$ \\
\hline Plant size & $\begin{array}{c}-0.07 \\
{[0.10]}\end{array}$ & $\begin{array}{c}-1.91 * * \\
{[0.94]}\end{array}$ \\
\hline Collective bargaining & $\begin{array}{l}1.22 * * * \\
{[0.33]}\end{array}$ & $\begin{array}{l}3.51 * * * \\
{[0.84]}\end{array}$ \\
\hline Works council & $\begin{array}{c}-0.03 \\
{[0.07]}\end{array}$ & $\begin{array}{c}-3.31^{* * *} \\
{[0.74]}\end{array}$ \\
\hline Export & $\begin{array}{c}-0.01 \\
{[0.07]}\end{array}$ & $\begin{array}{c}-0.74 \\
{[0.59]}\end{array}$ \\
\hline Technology & $\begin{array}{c}0.03 \\
{[0.03]}\end{array}$ & $\begin{array}{c}-0.82 \\
{[0.70]}\end{array}$ \\
\hline Investment per worker & $\begin{array}{c}0.01 \\
{[0.11]}\end{array}$ & $\begin{array}{c}-1.98 \\
{[1.26]}\end{array}$ \\
\hline Constant & & $\begin{array}{c}4.82 \\
{[3.78]}\end{array}$ \\
\hline Total & $\begin{array}{l}2.49 * * * \\
{[0.46]}\end{array}$ & $\begin{array}{l}6.31 * * * \\
{[0.52]}\end{array}$ \\
\hline Reweighting error & $\begin{array}{c}-0.15 \\
{[0.21]}\end{array}$ & \\
\hline Specification error & $\begin{array}{c}0.03 \\
{[0.22]}\end{array}$ & \\
\hline
\end{tabular}

Notes: The decomposition is based on LIAB data. The sample includes full-time male workers between 18 and 65 years of age who work in West Germany. Sampling weights are employed. All numbers are given in log percentage points. Bootstrapped standard errors (200 replications of the entire procedure) account for clustering at the plant level and are shown in brackets. Asterisks indicate statistical significance at the $1 \%(* * *), 5 \%(* *)$, or $10 \%(*)$ level.

decomposition results for between-plant and within-plant wage dispersion and, in further extensions, explore differences between lower-tail and upper-tail wage dispersion, changes over time, and differences between West and East Germany. 
Baseline decomposition of the change in overall wage inequality. The results of our baseline decomposition of changes in the log wage variance between 1996 and 2010 are presented in Table 2, where the values represent log percentage points and generally give the joint contribution of groups of (dummy) variables belonging to the explanatory factors listed in the left column of the table. In addition to composition and wage structure effects, we also report the specification and reweighting errors.

Looking first at the total composition and wage structure effects, respectively, reveals that the former contribute about 29 percent and the latter about 73 percent to the increase in wage dispersion over the sample period (where the difference to 100 percent is accounted for by the negative reweighting error). Among the composition effects, the ones associated with collective bargaining coverage contribute the most to the increase in wage dispersion. This reflects the strong decline in (particularly sector-level) collective bargaining coverage rates discussed in the previous section. As shown in the same section, this decline supposes a relative shift toward the group of (uncovered) workers characterized by both higher intra-group wage dispersion and groupmean wages that are relatively far from the grand mean. The contribution of the bargaining-related composition effect amounts to $1.22 \mathrm{log}$ percentage points, which corresponds to 14.1 percent of the total increase and about half of the total composition effect, respectively. Among the remaining composition effects, only shifts in the education profile of workers have played a small, but non-negligible role, contributing $0.7 \log$ percentage points to the rise in wage inequality. They capture the relative shifts toward higher-educated workers, i.e., a group characterized by group-mean wages that are relatively far from the grand mean.

Turning to the wage structure effects, the ones associated with industry fixed effects and, once more, collective bargaining, are the quantitatively most important ones (4.04 and 3.51 log percentage points, respectively). Recall that the wage structure effects capture both a between component, that is, changes in wage differentials between groups (e.g., industries, different bargaining regimes), and a within component, that is, changes in wage dispersion within groups (compared to the base group). In the case of collective bargaining, both of these components are at work and contribute to greater wage dispersion. On the one hand, the wage gap between covered and uncovered workers increased slightly, and on the other hand, wage dispersion within the group of workers covered by (sector-level) agreements rose much more strongly than among uncovered ones, our base group (see the previous section). The latter development has also been highlighted by Dustmann et al. (2014) and is related to an increasing flexibility within collective agreements. A similar story applies to the industry-related wage structure effect, which captures both increasing 
industry mean wage differentials and a growing wage dispersion within industries. While the RIF-based decomposition result does not allow us to disentangle the two, the latter channel seems to be the more important one. That is, if we do the same simple decomposition of the log wage variance into a between and a within component as in the Trends in German Wage Inequality section, but this time focus on industries rather than plants, it turns out that approximately 70 percent of the increase in wage inequality over our period of analysis took place within, as opposed to between, industries.

Among the remaining wage structure effects, the ones relating to education and age contribute positively to rising wage dispersion, while the ones associated with tenure, the existence of a works council, plant size, and investment per worker dampen it, although the latter is not statistically significant. The other wage structure effects are not important determinants of greater wage dispersion. $^{29}$

Comparing our baseline decomposition results to the related paper by Biewen and Seckler (2019), we see both similarities and differences. Based on their analysis of the alternative GSES data, they also attributed the largest composition effect to the decline of union coverage. However, they found this decline to be quantitatively much more important. Biewen and Seckler (2019) put this down to the fact that the GSES data have information on collective bargaining coverage at the worker level as opposed to the plant (or firm) level, which is the information provided in the LIAB data. This explanation would also be consistent with the difference in the bargaining-related wage structure effect, which is very important in our analysis, yet negligible in Biewen and Seckler (2019). ${ }^{30}$ Again, one explanation might be that what we view as greater wage dispersion among workers at covered plants (wage structure) is driven by a declining share of workers at those plants that are actually subject to collective agreements (composition). However, one challenge to this interpretation is that we would expect these differences to matter (at least partly) for within-plant wage inequality, while we find both the bargaining-related composition and the wage structure effects to be relevant almost exclusively

\footnotetext{
29 This includes the wage structure effect related to exporting. The latter result stands in contrast to the one obtained by Baumgarten (2013) who, however, focused on the manufacturing sector only and considered a slightly different sampling period-the analysis of Baumgarten (2013) ends in 2007, that is, before the exporter wage premium decreased during the Great Recession (see Dauth, Schmerer, and Winkler 2015). Moreover, we include a larger set of plant-level control variables and apply a slightly different decomposition technique.

${ }^{30}$ Both our results of an important, but more moderate composition effect of collective bargaining and a substantial role played by a greater wage dispersion among covered plants are in line with the findings of Dustmann, Ludsteck, and Schönberg (2009) and Dustmann et al. (2014), yet arrived at in a multivariate setting. This is not surprising, as we rely on the same data source.
} 
for between-plant wage inequality (see below). Additional reasons for the quantitative discrepancy likely are that (1) we control for more employer-level variables, and (2) the sample composition is different, as the GSES data does not include firms with fewer than ten employees subject to social security contributions and does not cover all the sectors of the economy. The latter factor most likely also explains why we find an industry-related wage structure effect that is much larger than in Biewen and Seckler (2019).

Decomposition of changes in between-plant and within-plant wage inequality. We now separately decompose changes in between-plant and within-plant wage dispersion. For this purpose, we apply the same decomposition technique to changes in the variance of predicted wages and wage residuals, respectively, of a regression of log individual wages on a full set of plant fixed effects. At first sight, a natural expectation could be that plant characteristics, with their composition and wage structure effects, should be the main drivers of between-plant wage dispersion while individual characteristics should be the main drivers of within-plant wage dispersion. However, that does not need to be the case. To the extent that individual characteristics also matter for between-plant wage inequality, this suggests that workers with different characteristics are unevenly distributed across plants, providing (indirect) evidence for assortative matching. Indeed, previous research has already shown the growing importance of assortative matching, as measured by the correlation between individual and plant effects, for wage inequality (Card, Heining, and Kline 2013). On the other hand, to the extent that plant characteristics matter for within-plant wage dispersion, this suggests that these characteristics affect individual workers' wages unevenly.

We first turn to the detailed decomposition results of between-plant wage inequality, shown in the left part of Table 3. As the increase in the betweenplant variance accounts for the largest part of the increase in the overall variance, it is not surprising that the main factors contributing to the rise are identical. Again, most of the increase (roughly 80 percent) is due to wage structure effects. Among the composition effects (column 1), the largest contribution to the increase in between-plant wage inequality again comes from changes in collective bargaining coverage rates. The bargaining-related composition effect amounts to $1.29 \mathrm{log}$ percentage points (corresponding to 18 percent of the total increase in between-plant wage inequality or 74 percent of the total composition effect) and is, thus, even slightly larger than in the case of overall inequality, both in relative and absolute terms. Thus, the decline in collective bargaining, driven primarily by a strongly decreasing share of plants covered by sector-level agreements, has come with a greater dispersion of wages across plants. Among the composition effects related to individual characteristics, 
TABLE 3

Decomposition of Changes in Between-Plant and Within-Plant Variance, 1996-2010

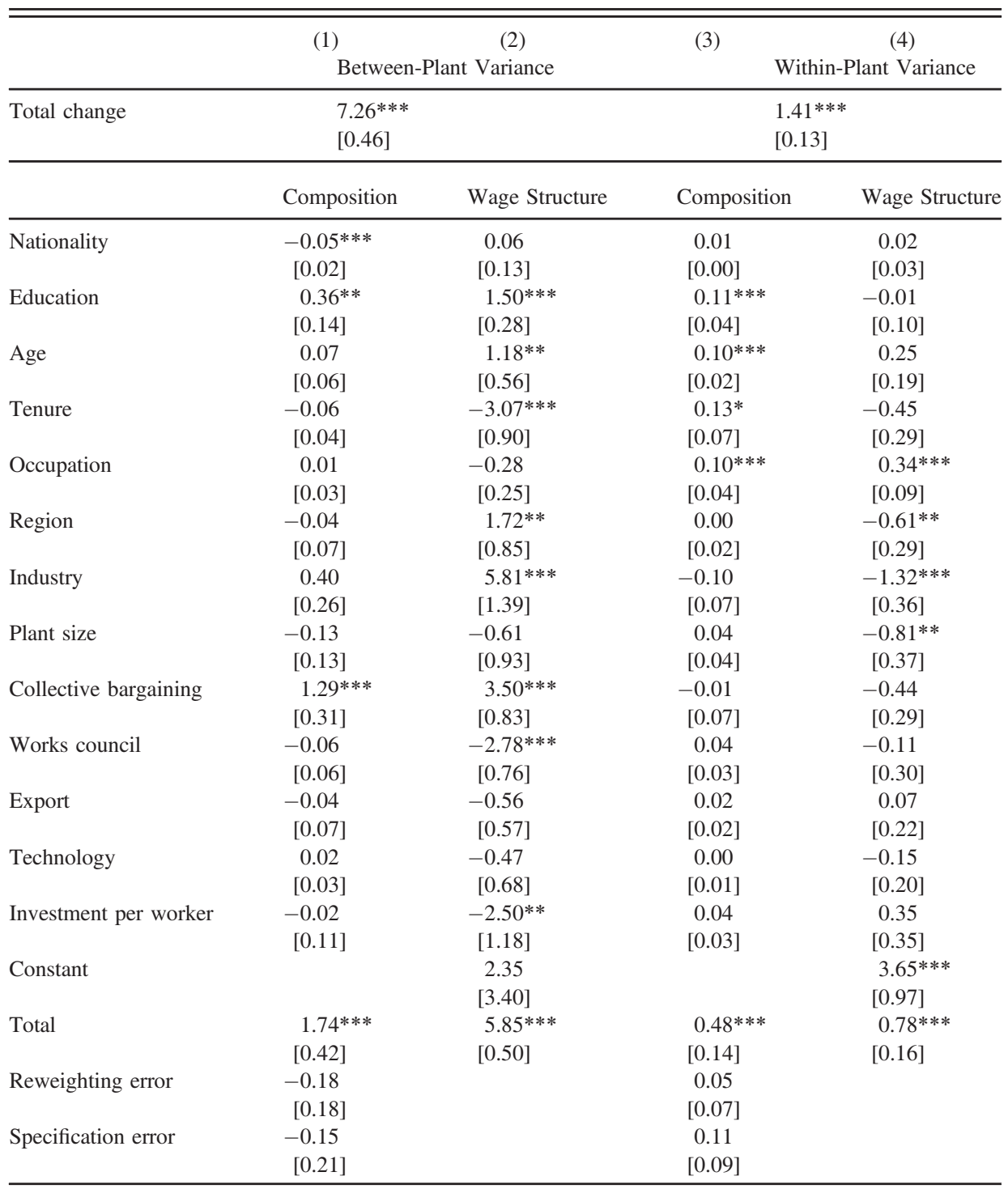

Notes: The between-plant (within-plant) variance is constructed as the variance of predicted (residual) wages of a regression of $\log$ individual wages on a full set of plant fixed effects. The decomposition is based on LIAB data. The sample includes full-time male workers between 18 and 65 years of age who work in West Germany. Sampling weights are employed. All numbers are given in log percentage points. Bootstrapped standard errors (200 replications of the entire procedure) account for clustering at the plant level and are shown in brackets. Asterisks indicate statistical significance at the $1 \%(* *), 5 \%(* *)$, or $10 \%(*)$ level. 


\section{0 / Daniel Baumgarten, Gabriel Felbermayr, and Sybille Lehwald}

(only) the explanatory factor education contributes non-negligibly to the rise in between-plant wage dispersion. The latter's contribution amounts to $0.36 \mathrm{log}$ percentage points, corresponding to 5 percent of the total increase in betweenplant wage inequality or, equivalently, to 20 percent of the total composition effect.

Turning to the wage structure effects (column 2), consistent with our earlier findings, the ones associated with industry fixed effects and the collective bargaining regime contribute quantitatively the most to increasing between-plant wage inequality. In contrast, the wage structure effects associated with tenure, the existence of a works council, and the level of investment per worker are negative. This reflects that, for these categorical variables, between-plant wage dispersion within a given group has declined relative to the base group (workers with less than 2 years of tenure, plants without a works council, and plants in the bottom quintile of investment per worker, respectively). Among the wage structure effects associated with the remaining worker-level variables, it is again the one relating to education that stands out in contributing the most to greater between-plant wage inequality. The education-related wage structure effect mainly captures that plant-level wage differentials between education groups have increased. That is, the gap between the mean plant wage of a high-skilled and a low-skilled worker and between a high-skilled and one with missing information on education has increased substantially over time (by 17 and $21 \log$ percentage points, respectively). This is consistent with the notion of increased assortative matching along the skill dimension, where high-skilled workers are more and more concentrated at high-wage paying plants and lowskilled workers at low-wage paying plants. This result is in line with Card, Heining, and Kline (2013), who also find that the degree of sorting of different education and occupation groups to different establishments has risen in West Germany. 31

We now turn to the results on within-plant wage inequality (columns 3 and 4). The most striking finding is that by far the largest contribution to the increase in this subcomponent of wage inequality comes from the wage structure effect associated with the constant, which captures the increase in residual inequality of the base group. In fact, the latter is more than twice as large as the total observed increase in within-plant inequality, implying that all remaining factors have, in sum, had a negative, i.e., inequality-dampening contribution.

If we look at those factors separately, only a few are statistically significant and/or noteworthy in terms of their magnitude. One of them is occupation,

\footnotetext{
${ }^{31} \mathrm{We}$ assume that workers with missing educational information are most likely low-skilled workers. According to their unconditional mean wages, this is a plausible assumption; see Table 1.
} 
which contributes positively and significantly to increased within-plant wage inequality both in terms of the composition and the wage structure effect. Recall that we have grouped occupations in terms of their task characteristics, distinguishing predominantly manual, routine (the base group), and abstract occupations. The composition effect reflects the relative decrease in the share of routine occupations characterized by lower within-plant wage dispersion and mean (plant-residualized) wages closer to the grand mean. The occupation-related wage structure effect, in turn, arises mainly from greater increases in within-plant wage dispersion among manual and, in particular, abstract occupations relative to routine ones. Among the remaining individual-level characteristics, compositional shifts toward larger shares of high-educated and older workers as well as those with longer tenure have also led to higher within-plant wage inequality.

Interestingly, the industry-related wage structure effect, the single most important factor for increased between-plant wage dispersion, contributes negatively to within-plant wage dispersion. Because there are no differences across industries in terms of their mean within-plant wages - they are zero by construction - this is due to a relatively smaller increase in within-plant wage dispersion among industries other than the base industry, i.e., construction. In addition, collective bargaining, which was another main factor for increased between-plant wage dispersion, does not matter at all for changes in withinplant wage dispersion.

In summary, this analysis shows that the main sources of between-plant and within-plant wage dispersion differ and some explanatory factors even are related to both subcomponents of wage inequality in opposing ways. The most important explanatory factors for the large increase in between-plant wage inequality are the wage structure effects associated with the industry and the collective bargaining regime as well as the compositional shift implied by the strong decline in collective bargaining coverage. The worker-level characteristic education is the only one for which both the composition and wage structure effects are positively related to both subcomponents of wage dispersion. Interestingly, the wage structure effect associated with education is quantitatively more important for between-plant than for within-plant wage inequality. This mirrors the finding that most of the increase in the skill wage gap arises from an increase in between-plant rather than within-plant wage differentials.

Top versus bottom. Although the log wage variance has the advantage that the between-plant and the within-plant components add up to the total, it does not allow us to distinguish sources of wage dispersion at the top and the bottom of the wage distribution. Therefore, we also do our decomposition 


\section{2 / Daniel Baumgarten, Gabriel Felbermayr, and Sybille Lehwald}

analysis for the 50-15 log wage differential (as a measure of lower-tail wage inequality) and the 85-50 log wage differential (as a measure of upper-tail wage inequality) of both mean plant wages and within-plant wage residuals, respectively. ${ }^{32}$ Results are shown in Table 4.

As far as between-plant wage inequality is concerned (columns 1 and 2), more than two thirds of the increase in wage dispersion over the period of analysis (18.5 of $26.8 \mathrm{log}$ percentage points) occurred at the lower part of the wage distribution. This difference between lower-tail and upper-tail inequality is due to wage structure effects, while composition effects are, in sum, small and of about equal magnitude. The main contributing factors to the increase in lower-tail, between-plant wage dispersion are the wage structure effects related to industry fixed effects and the collective bargaining regime, which amount to 16.6 and $10.9 \log$ percentage points, respectively (column 1, bottom panel). In contrast, both of these factors do not matter for the change in upper-tail, between-plant wage dispersion, in which the wage structure effects associated with the region and the constant are quantitatively the most important ones (although the latter is not statistically significant; cf. column 2, bottom panel).

The composition effect associated with collective bargaining is again only relevant for lower-tail wage inequality. Thus, the decline in collective bargaining has been associated with a widening of the lower part of the plant wage distribution, where union wages are more likely to bind than in the upper part of the distribution.

The picture looks different for within-plant wage inequality (columns 3 and 4), where about 60 percent of the (small) increase in total wage dispersion over the sample period took place in the upper half of the wage distribution (1.96 of $3.31 \log$ percentage points). By far, the main source of this increase in upper-tail, within-plant wage dispersion is not related to any particular factor but to the wage structure effect of the constant, which captures an increase in residual inequality of the base group (column 4). The contribution of the constant amounts to $15 \mathrm{log}$ percentage points, which is more than seven (!) times larger than the total change in this inequality measure. Further contributions, which are statistically significant and positive but small, come from the explanatory factors education, occupation - both through the composition and the wage structure effects - and age, where only the composition effect is relevant. In contrast, wage structure effects associated with the region, the industry, and plant size are all highly negative, i.e., inequality-dampening, and statistically significant.

Finally, regarding the change in lower-tail, within-plant wage dispersion, hardly any results stand out, the main exceptions being the wage structure

\footnotetext{
${ }^{32}$ Note that, now, the between-plant and the within-plant component of any inequality measure do not anymore (necessarily) add up to the total.
} 
Between-Plant and Within-Plant Wage Dispersion / 113

TABLE 4

Decomposition of Changes in Between-Plant and Within-Plant Quantile Differences, 19962010

\begin{tabular}{|c|c|c|c|c|}
\hline \multirow[b]{2}{*}{ Inequality measure } & \multicolumn{2}{|c|}{ Between-Plant } & Within-Plant & (4) \\
\hline & $50-15$ & $85-50$ & $50-15$ & $85-50$ \\
\hline Total change & $\begin{array}{l}18.45^{* * *} \\
{[1.50]}\end{array}$ & $\begin{array}{l}8.35^{* * *} \\
{[1.35]}\end{array}$ & $\begin{array}{l}1.36^{* * *} \\
{[0.33]}\end{array}$ & $\begin{array}{l}1.96^{* * * *} \\
{[0.58]}\end{array}$ \\
\hline \multicolumn{5}{|l|}{ Composition } \\
\hline Nationality & $\begin{array}{r}-0.06^{*} \\
{[0.03]}\end{array}$ & $\begin{array}{c}0.02 \\
{[0.02]}\end{array}$ & $\begin{array}{c}0.02 \\
{[0.02]}\end{array}$ & $\begin{array}{c}0.01 \\
{[0.02]}\end{array}$ \\
\hline Education & $\begin{array}{r}0.39 * \\
{[0.22]}\end{array}$ & $\begin{array}{l}0.83^{* * *} \\
{[0.26]}\end{array}$ & $\begin{array}{l}0.25^{* *} \\
{[0.10]}\end{array}$ & $\begin{array}{c}0.33^{* *} \\
{[0.16]}\end{array}$ \\
\hline Age & $\begin{array}{c}-0.10 \\
{[0.12]}\end{array}$ & $\begin{array}{l}0.27 * * * \\
{[0.09]}\end{array}$ & $\begin{array}{c}-0.01 \\
{[0.08]}\end{array}$ & $\begin{array}{l}0.78^{* * *} \\
{[0.10]}\end{array}$ \\
\hline Tenure & $\begin{array}{c}-0.09 \\
{[0.11]}\end{array}$ & $\begin{array}{c}-0.14 \\
{[0.09]}\end{array}$ & $\begin{array}{c}-0.18^{* * *} \\
{[0.07]}\end{array}$ & $\begin{array}{c}-0.03 \\
{[0.06]}\end{array}$ \\
\hline Occupation & $\begin{array}{c}0.02 \\
{[0.07]}\end{array}$ & $\begin{array}{c}0.08 \\
{[0.06]}\end{array}$ & $\begin{array}{l}0.15^{* *} \\
{[0.06]}\end{array}$ & $\begin{array}{l}0.52^{* * *} \\
{[0.20]}\end{array}$ \\
\hline Region & $\begin{array}{c}-0.22 \\
{[0.22]}\end{array}$ & $\begin{array}{c}0.11 \\
{[0.21]}\end{array}$ & $\begin{array}{c}0.05 \\
{[0.06]}\end{array}$ & $\begin{array}{c}0.00 \\
{[0.08]}\end{array}$ \\
\hline Industry & $\begin{array}{c}1.03 * \\
{[0.59]}\end{array}$ & $\begin{array}{l}1.32 * \\
{[0.73]}\end{array}$ & $\begin{array}{c}0.08 \\
{[0.20]}\end{array}$ & $\begin{array}{c}-1.38 * * * \\
{[0.42]}\end{array}$ \\
\hline Plant size & $\begin{array}{c}-0.45 \\
{[0.28]}\end{array}$ & $\begin{array}{c}-0.23 \\
{[0.32]}\end{array}$ & $\begin{array}{c}0.03 \\
{[0.06]}\end{array}$ & $\begin{array}{c}0.23 \\
{[0.20]}\end{array}$ \\
\hline Collective bargaining & $\begin{array}{l}1.29 * * \\
{[0.59]}\end{array}$ & $\begin{array}{c}0.03 \\
{[0.46]}\end{array}$ & $\begin{array}{c}0.28 \\
{[0.18]}\end{array}$ & $\begin{array}{c}-0.36 \\
{[0.31]}\end{array}$ \\
\hline Works council & $\begin{array}{c}0.26 \\
{[0.26]}\end{array}$ & $\begin{array}{c}0.08 \\
{[0.21]}\end{array}$ & $\begin{array}{c}0.04 \\
{[0.06]}\end{array}$ & $\begin{array}{c}0.04 \\
{[0.12]}\end{array}$ \\
\hline Export & $\begin{array}{c}-0.01 \\
{[0.19]}\end{array}$ & $\begin{array}{c}0.35 \\
{[0.29]}\end{array}$ & $\begin{array}{c}-0.07 \\
{[0.06]}\end{array}$ & $\begin{array}{c}0.07 \\
{[0.11]}\end{array}$ \\
\hline Technology & $\begin{array}{c}-0.06 \\
{[0.09]}\end{array}$ & $\begin{array}{c}0.00 \\
{[0.09]}\end{array}$ & $\begin{array}{c}-0.01 \\
{[0.02]}\end{array}$ & $\begin{array}{c}0.01 \\
{[0.05]}\end{array}$ \\
\hline Investment per worker & $\begin{array}{c}0.17 \\
{[0.32]}\end{array}$ & $\begin{array}{c}-0.05 \\
{[0.27]}\end{array}$ & $\begin{array}{c}0.17^{*} \\
{[0.09]}\end{array}$ & $\begin{array}{c}0.09 \\
{[0.13]}\end{array}$ \\
\hline Total & $\begin{array}{l}2.19^{* *} \\
{[0.93]}\end{array}$ & $\begin{array}{l}2.68^{* *} \\
{[1.08]}\end{array}$ & $\begin{array}{l}0.80 * * * \\
{[0.30]}\end{array}$ & $\begin{array}{c}0.32 \\
{[0.55]}\end{array}$ \\
\hline Wage structure & & & & \\
\hline Nationality & $\begin{array}{c}0.20 \\
{[0.27]}\end{array}$ & $\begin{array}{c}-0.01 \\
{[0.09]}\end{array}$ & $\begin{array}{c}-0.06 \\
{[0.10]}\end{array}$ & $\begin{array}{c}-0.03 \\
{[0.09]}\end{array}$ \\
\hline Education & $\begin{array}{l}4.52 * * * \\
{[0.95]}\end{array}$ & $\begin{array}{c}-0.23 \\
{[0.66]}\end{array}$ & $\begin{array}{c}-0.79 * * \\
{[0.36]}\end{array}$ & $\begin{array}{c}0.94 * * \\
{[0.44]}\end{array}$ \\
\hline Age & $\begin{array}{c}-0.01 \\
{[1.15]}\end{array}$ & $\begin{array}{c}0.02 \\
{[0.86]}\end{array}$ & $\begin{array}{c}-0.75 \\
{[0.68]}\end{array}$ & $\begin{array}{c}0.37 \\
{[0.88]}\end{array}$ \\
\hline Tenure & $\begin{array}{c}-11.73 * * * \\
{[3.92]}\end{array}$ & $\begin{array}{c}-1.47 \\
{[1.38]}\end{array}$ & $\begin{array}{c}0.56 \\
{[0.77]}\end{array}$ & $\begin{array}{c}-0.35 \\
{[0.89]}\end{array}$ \\
\hline
\end{tabular}


TABLE 4 (CONTINUED)

\begin{tabular}{|c|c|c|c|c|}
\hline \multirow[b]{2}{*}{ Inequality measure } & \multicolumn{2}{|c|}{ Between-Plant } & \multicolumn{2}{|c|}{ Within-Plant } \\
\hline & $50-15$ & $85-50$ & $50-15$ & $85-50$ \\
\hline Occupation & $\begin{array}{c}-1.02 \\
{[0.73]}\end{array}$ & $\begin{array}{c}-0.31 \\
{[0.50]}\end{array}$ & $\begin{array}{l}0.62 * * \\
{[0.24]}\end{array}$ & $\begin{array}{l}1.02 * \\
{[0.53]}\end{array}$ \\
\hline Region & $\begin{array}{c}3.18 \\
{[3.19]}\end{array}$ & $\begin{array}{c}4.70^{*} \\
{[2.49]}\end{array}$ & $\begin{array}{c}-1.26^{*} \\
{[0.65]}\end{array}$ & $\begin{array}{c}-2.79 * * \\
{[1.12]}\end{array}$ \\
\hline Industry & $\begin{array}{l}16.62 * * \\
{[6.59]}\end{array}$ & $\begin{array}{c}2.34 \\
{[3.79]}\end{array}$ & $\begin{array}{c}-1.21 \\
{[1.09]}\end{array}$ & $\begin{array}{c}-4.82^{* * *} \\
{[1.48]}\end{array}$ \\
\hline Plant size & $\begin{array}{c}-5.42 \\
{[4.53]}\end{array}$ & $\begin{array}{c}2.41 \\
{[4.26]}\end{array}$ & $\begin{array}{l}2.08 * * * \\
{[0.79]}\end{array}$ & $\begin{array}{c}-4.77 * * \\
{[2.09]}\end{array}$ \\
\hline Collective bargaining & $\begin{array}{l}10.94 * * \\
{[4.37]}\end{array}$ & $\begin{array}{c}-1.92 \\
{[2.50]}\end{array}$ & $\begin{array}{c}0.02 \\
{[0.68]}\end{array}$ & $\begin{array}{c}-2.05 \\
{[1.30]}\end{array}$ \\
\hline Works council & $\begin{array}{c}-8.99 * * \\
{[3.76]}\end{array}$ & $\begin{array}{c}-2.42 \\
{[2.60]}\end{array}$ & $\begin{array}{l}1.07^{*} \\
{[0.56]}\end{array}$ & $\begin{array}{c}-1.39 \\
{[1.43]}\end{array}$ \\
\hline Export & $\begin{array}{c}-0.56 \\
{[2.36]}\end{array}$ & $\begin{array}{c}-2.88 \\
{[2.11]}\end{array}$ & $\begin{array}{c}-0.28 \\
{[0.50]}\end{array}$ & $\begin{array}{c}-0.37 \\
{[1.09]}\end{array}$ \\
\hline Technology & $\begin{array}{r}-5.40^{*} \\
{[2.77]}\end{array}$ & $\begin{array}{c}0.69 \\
{[1.75]}\end{array}$ & $\begin{array}{c}0.22 \\
{[0.53]}\end{array}$ & $\begin{array}{c}-0.24 \\
{[0.72]}\end{array}$ \\
\hline Investment per worker & $\begin{array}{c}-2.63 \\
{[4.40]}\end{array}$ & $\begin{array}{c}-0.05 \\
{[2.33]}\end{array}$ & $\begin{array}{l}2.25^{* * *} \\
{[0.76]}\end{array}$ & $\begin{array}{c}-0.18 \\
{[1.16]}\end{array}$ \\
\hline Constant & $\begin{array}{c}16.11 \\
{[11.02]}\end{array}$ & $\begin{array}{c}4.81 \\
{[10.57]}\end{array}$ & $\begin{array}{c}-1.30 \\
{[2.39]}\end{array}$ & $\begin{array}{l}15.02 * * * \\
{[4.88]}\end{array}$ \\
\hline Total & $\begin{array}{l}15.81 * * * \\
{[2.02]}\end{array}$ & $\begin{array}{l}5.68^{* * *} \\
{[1.43]}\end{array}$ & $\begin{array}{l}1.17 * * * \\
{[0.43]}\end{array}$ & $\begin{array}{c}0.35 \\
{[0.84]}\end{array}$ \\
\hline Reweighting error & $\begin{array}{c}-0.36 \\
{[0.36]}\end{array}$ & $\begin{array}{c}-0.35 \\
{[0.40]}\end{array}$ & $\begin{array}{c}0.10 \\
{[0.13]}\end{array}$ & $\begin{array}{c}0.26 \\
{[0.24]}\end{array}$ \\
\hline Specification error & $\begin{array}{c}0.81 \\
{[1.11]}\end{array}$ & $\begin{array}{c}0.34 \\
{[1.08]}\end{array}$ & $\begin{array}{c}-0.72 * * * \\
{[0.24]}\end{array}$ & $\begin{array}{l}1.02^{*} \\
{[0.57]}\end{array}$ \\
\hline
\end{tabular}

Notes: The between-plant (within-plant) quantile differences are constructed as percentile differences (50-15 and 85-50, respectively) of predicted (residual) wages of a regression of log individual wages on a full set of plant fixed effects. The decomposition is based on LIAB data. The sample includes full-time male workers between 18 and 65 years of age who work in West Germany. Sampling weights are employed. All numbers are given in log percentage points. Bootstrapped standard errors (200 replications of the entire procedure) account for clustering at the plant level and are shown in brackets. Asterisks indicate statistical significance at the $1 \%(* * *), 5 \%(* *)$, or $10 \%(*)$ level.

effects related to plant size and investment per worker, which are statistically significant and amount to 2.1 and $2.3 \mathrm{log}$ percentage points, respectively (column 3). Thus, increases in wage dispersion within plants in a given plant size and investment per worker category (relative to the respective base groups, i.e., plants with 200-499 workers and in the bottom quintile of investment intensity) were important factors behind the (modest) increase in lower-tail, within-plant wage inequality.

The recent decline in wage inequality. So far, we have analyzed the contributions of the different factors to the change in wage dispersion over the period 1996-2010, which was characterized by a pronounced and fairly steady 
increase in wage inequality. Thereafter, however, rising wage dispersion seems to have come to a halt. In this subsection, we conduct the same decomposition analysis for the change in wage inequality between 2010 and 2014 to obtain a better understanding of the change in the inequality dynamics. We again do so separately for changes in overall, between-plant, and within-plant wage dispersion. Results are displayed in Table 5.

In the following, we highlight a few noteworthy findings. First of all, the decline in the log wage variance has been very modest $(0.47$ log percentage points) and has been entirely due to the between-plant component, while withinplant wage dispersion continued to rise slightly. Interestingly, for all of our wage dispersion measures, the total composition effects are positive (i.e., inequality-increasing) while the total wage structure effects are inequality-dampening. This result, however, has to be interpreted with some caution. Due to a change in the compulsory notifications of employers to the social security agencies implemented for employment spells ending after November 30, 2011, the set of available variables and their exact definitions in the administrative records used in our analysis changed during the most recent time interval. ${ }^{33}$ As a consequence, the share of missing data, in particular regarding the education variable, increased sharply (from 14 to 28 percent, mostly at the expense of low-skilled and medium-skilled workers). This implies a seeming change in the composition of the workforce, which is entirely data-driven, but clearly affects the decomposition results. Indeed, the spurious education-related composition effect is positive, statistically significant, and quantitatively the most important one for all the measures of wage dispersion (columns 1, 3, and 5). Likewise, the education-related wage structure effect, which is negative and substantial for the change in the overall and the between-plant variance (columns 2 and 4), is rather misleading, too, as the apparent "returns" to, e.g., missing education were severely altered due to the large increase in missing data.

Regarding the change in the between-plant wage variance (columns 3 and 4), wage structure effects associated with the constant, investment per worker, the collective bargaining regime, the industry, and the level of education (see above) contribute the most to declining wage dispersion in terms of the point estimate, but, apart from education, none of them is statistically significant. Still, apart from investment, which had an inequality-dampening contribution

\footnotetext{
33 As Fitzenberger and Seidlitz (2020) note, there has also been a break in the part-time indicator as a result of this reporting change. They argue that the incidence of part-time work was likely underestimated before 2011. However, they also find that this does not affect wage inequality trends among full-time workers in West Germany until 2010. It might, however, affect the results for the change in wage inequality in the more recent time period, to the extent that this break and the potential change in the sample composition is not accounted for by our extensive set of control variables.
} 
116 / Daniel Baumgarten, Gabriel Felbermayr, and Sybille Lehwald

TABLE 5

Decomposition of Changes in the Overall, Between-Plant, and Within-Plant Variance, 2010-2014

\begin{tabular}{|c|c|c|c|c|c|c|}
\hline & (1) & (2) & & (4) & (5) & (6) \\
\hline & & & Betwee & n-Plant & With & n-Plant \\
\hline & Overall & Jariance & Varianc & & Vari & nce \\
\hline Total change & -0.47 & & -0.64 & & 0.18 & \\
\hline & & Wage & & Wage & & Wage \\
\hline & Composition & Structure & Composition & Structure & Composition & Structure \\
\hline Nationality & $0.07 * * *$ & -0.14 & $0.08 * * *$ & -0.11 & 0.00 & $-0.10 * * *$ \\
\hline & {$[0.03]$} & {$[0.16]$} & [0.02] & [0.13] & {$[0.00]$} & [0.03] \\
\hline Education & $1.28 * * *$ & $-1.24 * * *$ & $0.86^{* * *}$ & $-0.82 * *$ & $0.13 * * *$ & -0.08 \\
\hline & {$[0.21]$} & [0.39] & {$[0.20]$} & [0.34] & {$[0.04]$} & [0.12] \\
\hline Age & $0.12 * * *$ & -0.84 & $0.08 * * *$ & -0.16 & $0.06 * * *$ & -0.04 \\
\hline & {$[0.04]$} & {$[0.60]$} & {$[0.03]$} & {$[0.52]$} & {$[0.02]$} & {$[0.16]$} \\
\hline Tenure & $0.27 * * *$ & -0.51 & $0.23 * * *$ & $1.12 *$ & 0.05 & $-1.33 * * *$ \\
\hline & [0.09] & {$[0.80]$} & {$[0.06]$} & {$[0.65]$} & {$[0.04]$} & {$[0.25]$} \\
\hline Occupation & $0.15 * * *$ & 0.25 & $-0.08 * *$ & 0.24 & $0.11 * * *$ & 0.13 \\
\hline & {$[0.05]$} & {$[0.30]$} & {$[0.04]$} & {$[0.27]$} & {$[0.02]$} & {$[0.10]$} \\
\hline Region & 0.06 & 1.03 & 0.05 & 0.77 & 0.01 & 0.29 \\
\hline & {$[0.06]$} & {$[0.83]$} & {$[0.06]$} & {$[0.80]$} & {$[0.01]$} & {$[0.23]$} \\
\hline Industry & 0.18 & -0.11 & 0.24 & -0.87 & -0.04 & $0.80 * *$ \\
\hline & {$[0.18]$} & [1.52] & {$[0.20]$} & [1.41] & {$[0.03]$} & {$[0.33]$} \\
\hline Plant size & -0.15 & 1.21 & -0.15 & 1.32 & -0.01 & -0.13 \\
\hline & {$[0.15]$} & {$[1.01]$} & {$[0.15]$} & [1.01] & {$[0.03]$} & {$[0.27]$} \\
\hline Collective & 0.05 & -1.08 & 0.02 & -1.05 & $0.05 * * *$ & 0.08 \\
\hline bargaining & {$[0.05]$} & {$[0.80]$} & {$[0.05]$} & {$[0.76]$} & {$[0.02]$} & {$[0.21]$} \\
\hline Works council & $0.28 * * *$ & $1.19^{*}$ & $0.24 * * *$ & $1.17 *$ & 0.02 & 0.00 \\
\hline & {$[0.10]$} & {$[0.66]$} & [0.09] & [0.67] & {$[0.01]$} & {$[0.20]$} \\
\hline Export & 0.05 & 0.72 & 0.05 & 0.05 & -0.01 & $0.55^{* * *}$ \\
\hline & {$[0.04]$} & [0.59] & {$[0.04]$} & {$[0.56]$} & {$[0.01]$} & {$[0.18]$} \\
\hline Technology & $-0.11 * *$ & $1.30 *$ & -0.07 & 1.17 & 0.01 & 0.07 \\
\hline & {$[0.05]$} & {$[0.77]$} & {$[0.04]$} & {$[0.78]$} & {$[0.01]$} & {$[0.23]$} \\
\hline Investment per & -0.05 & -1.02 & -0.08 & -1.37 & $-0.04 *$ & 0.49 \\
\hline worker & {$[0.08]$} & [2.87] & {$[0.10]$} & [1.16] & {$[0.02]$} & {$[0.33]$} \\
\hline Constant & & -3.00 & & -3.14 & & -0.87 \\
\hline & & [4.43] & & [2.97] & & {$[0.80]$} \\
\hline Total & $2.20 * * *$ & $-2.24 * * *$ & $1.47 * * *$ & $-1.68 * * *$ & $0.32 * * *$ & -0.12 \\
\hline & {$[0.37]$} & {$[0.49]$} & {$[0.35]$} & {$[0.46]$} & {$[0.08]$} & {$[0.12]$} \\
\hline Reweighting error & $-0.36^{* * *}$ & & $-0.34 * * *$ & & $-0.05 * *$ & \\
\hline & {$[0.11]$} & & {$[0.11]$} & & {$[0.02]$} & \\
\hline Specification & -0.07 & & -0.09 & & 0.02 & \\
\hline error & [0.12] & & {$[0.11]$} & & {$[0.02]$} & \\
\hline
\end{tabular}

Notes: The between-plant (within-plant) variance is constructed as the variance of predicted (residual) wages of a regression of log individual wages on a full set of plant fixed effects. The decomposition is based on LIAB data. The sample includes full-time male workers between 18 and 65 years of age who work in West Germany. Sampling weights are employed. All numbers are given in log percentage points. Bootstrapped standard errors (200 replications of the entire procedure) account for clustering at the plant level and are shown in brackets. Asterisks indicate statistical significance at the $1 \%(* * *), 5 \%(* *)$, or $10 \%(*)$ level. 
already in the earlier period, and the constant, all of the other mentioned factors were important for the increase in between-plant wage dispersion between 1996 and 2010. Thus, while some of the most important factors for betweenplant wage inequality remain the same, the sign of their contribution changed, turning from inequality-increasing to inequality-dampening.

This is not true regarding the slight increase in within-plant wage dispersion (columns 5 and 6). Here, the wage structure effects associated with the industry and exporting are statistically significant and quantitatively the most important ones, which constitutes a change with respect to the earlier period. While exporting did not play a role at all in the period 1996-2010, the industry wage structure effect was negative. Because the wage structure effect of plant-level variables captures differential changes in within-group wage dispersion relative to the base category, this implies that, compared to the construction industry (the base category), within-plant wage dispersion in the remaining industries was rising by less in the earlier period, but by more in the years 2010-2014.

Wage inequality in East Germany. Our main analysis focused on West Germany to allow for a better comparison of our results with seminal earlier papers on the topic (Card, Heining, and Kline 2013; Dustmann, Ludsteck, and Schönberg 2009). Furthermore, because the labor markets and wage schedules in West and East Germany differ markedly-even today, but particularly in the 1990s-pooling both regions would likely have contaminated the decomposition results. In this subsection, we briefly report on the decomposition results for East Germany. We focus on our main period of analysis, 1996 to 2010. Results are displayed in Table $6 .{ }^{34}$

We focus on a few notable similarities and differences with respect to West Germany. First of all, the increase in wage dispersion has been smaller than in the West (5.2 as opposed to $8.7 \mathrm{log}$ percentage points in terms of the total variance, starting from a slightly higher initial level of inequality). Yet, the relative importance of the between-plant and the within-plant component to the total increase has been similar, with the former's contribution amounting to 86 percent. Like in the West, the industry-related wage structure effect contributes the most to total and between-plant wage dispersion (columns 2 and 4). In addition, shifts in the industry structure of employment (i.e., the composition effect) also contributed toward higher inequality (columns 1 and 3), which was not the case in the West. In

\footnotetext{
${ }^{34}$ There is one difference in the specification between East and West Germany. Because East German workers are reliably recorded in the social security data only from 1992 onward, the tenure variable is leftcensored, and particularly severely so in 1996. We therefore only keep the tenure categories 0-2 years, 24 years, $>4$ years, and missing tenure.
} 


\section{8 / Daniel Baumgarten, Gabriel Felbermayr, and Sybille Lehwald}

TABLE 6

Decomposition of Changes in the Overall, Between-Plant, and Within-Plant Variance in EASt Germany, 1996-2010

\begin{tabular}{|c|c|c|c|c|c|c|}
\hline & \multicolumn{2}{|c|}{ Overall Variance } & \multicolumn{2}{|c|}{$\begin{array}{l}\text { Between-Plant } \\
\text { Variance }\end{array}$} & \multicolumn{2}{|c|}{$\begin{array}{l}\text { Within-Plant } \\
\text { Variance }\end{array}$} \\
\hline \multirow[t]{2}{*}{ Total change } & $\begin{array}{l}5.15^{* * *} * \\
{[0.59]}\end{array}$ & & $\begin{array}{l}4.42 * * \\
{[0.57]}\end{array}$ & & $\begin{array}{l}0.73 \\
{\left[0.1^{1}\right.}\end{array}$ & \\
\hline & Composition & $\begin{array}{l}\text { Wage } \\
\text { Structure }\end{array}$ & Composition & $\begin{array}{l}\text { Wage } \\
\text { Structure }\end{array}$ & Composition & $\begin{array}{l}\text { Wage } \\
\text { Structure }\end{array}$ \\
\hline Nationality & $\begin{array}{c}0.12 \\
{[0.10]}\end{array}$ & $\begin{array}{c}-0.33 \\
{[0.22]}\end{array}$ & $\begin{array}{c}0.08 \\
{[0.08]}\end{array}$ & $\begin{array}{c}-0.37 \\
(0.23]\end{array}$ & $\begin{array}{c}0.04 \\
{[0.03]}\end{array}$ & $\begin{array}{c}0.00 \\
{[0.03]}\end{array}$ \\
\hline Education & $\begin{array}{c}-0.19 \\
{[0.21]}\end{array}$ & $\begin{array}{l}1.67 * * * \\
{[0.37]}\end{array}$ & $\begin{array}{r}-0.07 \\
{[0.09]}\end{array}$ & $\begin{array}{l}0.93 * * * \\
(0.31]\end{array}$ & $\begin{array}{r}-0.02 \\
{[0.02]}\end{array}$ & $\begin{array}{l}0.31^{* *} \\
{[0.15]}\end{array}$ \\
\hline Age & $\begin{array}{l}0.43 * * * \\
{[0.07]}\end{array}$ & $\begin{array}{c}0.33 \\
{[0.77]}\end{array}$ & $\begin{array}{l}0.10^{* *} \\
{[0.05]}\end{array}$ & $\begin{array}{l}-0.79 \\
(0.56]\end{array}$ & $\begin{array}{l}0.16^{* * * *} \\
{[0.03]}\end{array}$ & $\begin{array}{c}-0.07 \\
{[0.21]}\end{array}$ \\
\hline Tenure & $\begin{array}{c}-0.16^{*} \\
{[0.10]}\end{array}$ & $\begin{array}{c}-2.24 * * \\
{[1.14]}\end{array}$ & $\begin{array}{c}-0.12 \\
{[0.10]}\end{array}$ & $\begin{array}{c}-2.19^{* *} \\
(0.98]\end{array}$ & $\begin{array}{c}0.00 \\
{[0.05]}\end{array}$ & $\begin{array}{c}-0.08 \\
{[0.41]}\end{array}$ \\
\hline Occupation & $\begin{array}{c}-0.11 \\
{[0.14]}\end{array}$ & $\begin{array}{c}0.39 \\
{[0.36]}\end{array}$ & $\begin{array}{c}0.00 \\
{[0.02]}\end{array}$ & $\begin{array}{c}0.13 \\
(0.30]\end{array}$ & $\begin{array}{r}-0.10 \\
{[0.13]}\end{array}$ & $\begin{array}{c}0.28 \\
{[0.17]}\end{array}$ \\
\hline Region & $\begin{array}{c}-0.01 \\
{[0.05]}\end{array}$ & $\begin{array}{c}0.96 \\
{[1.51]}\end{array}$ & $\begin{array}{c}0.00 \\
{[0.05]}\end{array}$ & $\begin{array}{c}0.87 \\
(1.43]\end{array}$ & $\begin{array}{c}-0.01 \\
{[0.02]}\end{array}$ & $\begin{array}{c}-0.24 \\
{[0.36]}\end{array}$ \\
\hline Industry & $\begin{array}{l}1.09 * * * \\
{[0.38]}\end{array}$ & $\begin{array}{l}3.53 * * * \\
{[1.04]}\end{array}$ & $\begin{array}{l}0.94 * * \\
{[0.40]}\end{array}$ & $\begin{array}{l}3.79 * * * \\
(1.01]\end{array}$ & $\begin{array}{c}0.21 \\
{[0.15]}\end{array}$ & $\begin{array}{c}-0.54 \\
{[0.42]}\end{array}$ \\
\hline Plant size & $\begin{array}{c}0.11 \\
{[0.14]}\end{array}$ & $\begin{array}{c}1.37 \\
{[1.17]}\end{array}$ & $\begin{array}{c}0.15 \\
{[0.22]}\end{array}$ & $\begin{array}{l}1.56 \\
(1.24]\end{array}$ & $\begin{array}{c}-0.09 \\
{[0.11]}\end{array}$ & $\begin{array}{c}-0.09 \\
{[0.43]}\end{array}$ \\
\hline $\begin{array}{l}\text { Collective } \\
\text { bargaining }\end{array}$ & $\begin{array}{l}0.41^{* *} \\
{[0.18]}\end{array}$ & $\begin{array}{c}0.55 \\
{[0.62]}\end{array}$ & $\begin{array}{l}0.35^{* *} \\
{[0.15]}\end{array}$ & $\begin{array}{c}0.69 \\
(0.60]\end{array}$ & $\begin{array}{c}0.08 \\
{[0.07]}\end{array}$ & $\begin{array}{c}-0.20 \\
{[0.22]}\end{array}$ \\
\hline Works council & $\begin{array}{c}0.04 \\
{[0.07]}\end{array}$ & $\begin{array}{c}0.82 \\
{[0.64]}\end{array}$ & $\begin{array}{c}-0.01 \\
{[0.04]}\end{array}$ & $\begin{array}{c}0.64 \\
(0.60]\end{array}$ & $\begin{array}{c}0.03 \\
{[0.04]}\end{array}$ & $\begin{array}{c}0.14 \\
{[0.22]}\end{array}$ \\
\hline Export & $\begin{array}{c}-0.04 \\
{[0.17]}\end{array}$ & $\begin{array}{c}-0.26 \\
{[0.56]}\end{array}$ & $\begin{array}{c}0.04 \\
{[0.16]}\end{array}$ & $\begin{array}{c}-0.15 \\
(0.53]\end{array}$ & $\begin{array}{c}-0.01 \\
{[0.06]}\end{array}$ & $\begin{array}{c}-0.03 \\
{[0.21]}\end{array}$ \\
\hline Technology & $\begin{array}{c}0.05 \\
{[0.06]}\end{array}$ & $\begin{array}{c}-0.04 \\
{[0.63]}\end{array}$ & $\begin{array}{c}-0.01 \\
{[0.06]}\end{array}$ & $\begin{array}{c}-0.10 \\
(0.63]\end{array}$ & $\begin{array}{c}0.04 \\
{[0.03]}\end{array}$ & $\begin{array}{c}0.04 \\
{[0.23]}\end{array}$ \\
\hline $\begin{array}{l}\text { Investment per } \\
\text { worker }\end{array}$ & $\begin{array}{c}0.21 * \\
{[0.13]}\end{array}$ & $\begin{array}{c}-1.31 \\
{[1.16]}\end{array}$ & $\begin{array}{l}0.32 * * \\
{[0.14]}\end{array}$ & $\begin{array}{c}-0.82 \\
(1.11]\end{array}$ & $\begin{array}{r}-0.06 \\
{[0.06]}\end{array}$ & $\begin{array}{c}-0.12 \\
{[0.33]}\end{array}$ \\
\hline Constant & & $\begin{array}{r}-1.02 \\
{[2.96]}\end{array}$ & & $\begin{array}{l}-0.46 \\
(2.92]\end{array}$ & & $\begin{array}{c}1.05 \\
{[0.91]}\end{array}$ \\
\hline Total & $\begin{array}{l}1.95^{* * *} \\
{[0.72]}\end{array}$ & $\begin{array}{l}4.41 * * * \\
{[0.68]}\end{array}$ & $\begin{array}{l}1.78^{* * * *} \\
{[0.67]}\end{array}$ & $\begin{array}{l}3.74 * * * \\
(0.64]\end{array}$ & $\begin{array}{c}0.27 \\
{[0.23]}\end{array}$ & $\begin{array}{c}0.45^{*} \\
{[0.24]}\end{array}$ \\
\hline Reweighting error & $\begin{array}{c}-0.67 \\
{[0.51]}\end{array}$ & & $\begin{array}{c}-0.61 \\
{[0.45]}\end{array}$ & & $\begin{array}{c}0.00 \\
{[0.19]}\end{array}$ & \\
\hline Specification error & $\begin{array}{r}-0.54^{*} \\
{[0.32]}\end{array}$ & & $\begin{array}{c}-0.48^{*} \\
{[0.29]}\end{array}$ & & $\begin{array}{c}0.00 \\
{[0.13]}\end{array}$ & \\
\hline
\end{tabular}

Notes: The between-plant (within-plant) variance is constructed as the variance of predicted (residual) wages of a regression of log individual wages on a full set of plant fixed effects. The decomposition is based on LIAB data. The sample includes full-time male workers between 18 and 65 years of age who work in East Germany. Sampling weights are employed. All numbers are given in log percentage points. Bootstrapped standard errors (200 replications of the entire procedure) account for clustering at the plant level and are shown in brackets. Asterisks indicate statistical significance at the $1 \%(* *), 5 \%(* *)$, or $10 \%(*)$ level. 
contrast, while (the decline in) collective bargaining does also matter in terms of the composition effect, the bargaining-related wage structure effect is not a factor behind the increase in wage dispersion in the East. As far as other explanatory factors are concerned, changes in the education-related wage structure are of similar quantitative importance as in the West, overall (column 2). While they contribute slightly less to between-plant wage dispersion (column 4), they matter more for changes in within-plant wage dispersion (column 6) than in West Germany.

In sum, however, despite the aforementioned differences, the dynamics of wage dispersion and its main sources have been remarkably similar in West and East Germany.

\section{Summary and Conclusion}

Like many other countries, Germany experienced a strong increase in wage dispersion in the last few decades before coming to a halt after 2010. Much of this increase took place between plants as opposed to within plants, in line with an increasing body of international evidence.

In this article, we have used rich linked employer-employee data to conduct a detailed decomposition analysis based on RIF regressions. This allows us to identify the sources of the increase in wage dispersion in Germany. In our analysis, we have paid particular attention to the importance of many different plant characteristics and to the divergent sources of between-plant and withinplant wage dispersion, respectively.

Our main decomposition results point to shifts in the industry-related wage structure, the decline in collective bargaining coverage, and changes in the bargaining-related wage structure as main sources of the increase in wage inequality. These factors affected primarily between-plant as opposed to within-plant and lower-tail as opposed to upper-tail wage dispersion. Among the individual-level variables, education matters the most, where both employment shifts toward more highly skilled workers and, even more so, changes in the skill-related wage structure have played important roles. The education-related effect is quantitatively more important for betweenplant than for within-plant wage inequality, reflecting increased sorting of workers along the skill dimension. In contrast, several other plant-level characteristics, including plant size, the exporting status, plant technology, and investment per worker are all of little if any quantitative importance for the increase in wage dispersion.

It is important to note, however, that, while the decomposition analysis has enabled us to identify the proximate sources of increased wage dispersion 


\section{0 / Daniel Baumgarten, Gabriel Felbermayr, and Sybille Lehwald}

between and within plants, we are not able to attach to them a causal interpretation in a deeper, structural sense. For example, changes in the industry-related and the bargaining-related wage structure did not come about exogenously. It is perfectly conceivable that these have been caused by changes in the competitive environment, potentially induced, e.g., by an accelerated globalization. ${ }^{35}$

Therefore, relating the proximate sources of rising wage inequality identified in our analysis to deeper structural causes is a high priority for future research.

\section{REFERENCES}

Abowd, John M., Francis Kramarz, and David N. Margolis. 1999. "High Wage Workers and High Wage Firms." Econometrica 67(2): 251-333.

Acemoglu, Daron, and David H. Autor. 2011. "Skills, Tasks and Technologies: Implications for Employment and Earnings." In Handbook of Labor Economics, Volume 4, Part B, edited by Orley Ashenfelter and David Card, pp. 1043-171. Amsterdam, the Netherlands: Elsevier.

Akerman, Anders, Elhanan Helpman, Oleg Itskhoki, Marc-Andreas Muendler, and Stephen Redding. 2013. "Sources of Wage Inequality." American Economic Review Papers and Proceedings 103(3): 214-19.

Antonczyk, Dirk, Bernd Fitzenberger, and Katrin Sommerfeld. 2010. "Rising Wage Inequality, the Decline of Collective Bargaining, and the Gender Wage Gap." Labour Economics 17(5): 835-47.

Autor, David H, Lawrence F Katz, and Melissa S Kearney. 2008. "Trends in U.S. Wage Inequality: Revising the Revisionists." Review of Economics and Statistics 90(2): 300-23.

Barth, Erling, Alex Bryson, James C. Davis, and Richard Freeman. 2016. "It's Where You Work: Increases in the Dispersion of Earnings across Establishments and Individuals in the United States." Journal of Labor Economics 34(2): S67-S97.

Baumgarten, Daniel. 2013. "Exporters and the Rise in Wage Inequality: Evidence from German Linked Employer-Employee Data." Journal of International Economics 90(1): 201-17.

— from Germany. CESifo Working Paper No. 7754. Munich, Germany: CESifo.

Biewen, Martin, Bernd Fitzenberger, and Jakob de Lazzer. 2018. "The Role of Employment Interruptions and Part-time Work for the Rise in Wage Inequality." IZA Journal of Labor Economics 7: 10.

— , and Daniela Plötze. 2019. "The Role of Hours Changes for the Increase in German Earnings Inequality." Jahrbücher für Nationalökonomie und Statistik 239(2): 277-304.

—_, and Matthias Seckler. 2019. "Changes in the German Wage Structure: Unions, Internationalization, Tasks, Firms, and Worker Characteristics.” Journal of Economic Inequality 17(4): 461-98.

Blinder, Alan S. 1973. "Wage Discrimination: Reduced Form and Structural Estimates." Journal of Human Resources 8(4): 436-55.

Card, David, Ana Rute Cardoso, Joerg Heining, and Patrick Kline. 2018. "Firms and Labor Market Inequality: Evidence and Some Theory.” Journal of Labor Economics 36(S1): S13-S70.

— Jörg Heining, and Patrick Kline. 2013. "Workplace Heterogeneity and the Rise of West German Wage Inequality." Quarterly Journal of Economics 128(3): 967-1015.

Chernozhukov, Victor, Iván Fernández-Val, and Blaise Melly. 2013. "Inference on Counterfactual Distributions." Econometrica 81(6): 2205-68.

${ }^{35}$ Dustmann et al. (2014) indeed suggest that rising opportunities to offshore production induced by the fall of the Iron Curtain contributed to a rising flexibilization of wages within the covered sector. Moreover, Baumgarten and Lehwald (2019) found that rising import penetration from China and Eastern Europe led to an increase in the probability of German plants leaving industry-wide collective bargaining agreements. 
Dauth, Wolfgang, Hans-Joerg Schmerer, and Erwin Winkler. 2015. "Exporters and Wage Inequality During the Great Recession-Evidence from Germany." Economics Letters 136: 137-40.

Davis, Steve J., and John Haltiwanger.1991. "Wage Dispersion Between and Within U.S. Manufacturing." NBER Working Paper No. 3722.Cambridge, MA: National Bureau of Economic Research.

DiNardo, John, Nicole M. Fortin, and Thomas Lemieux. 1996. "Labor Market Institutions and the Distribution of Wages, 1973-1992: A Semiparametric Approach.” Econometrica 64(5): 1001-44.

Dunne, Timothy, Lucia Foster, John Haltiwanger, and Kenneth R. Troske. 2004. "Wage and Productivity Dispersion in United States Manufacturing: The Role of Computer Investment." Journal of Labor Economics 22(2): 397-430.

Dustmann, Christian, Bernd Fitzenberger, Uta Schönberg, and Alexandra Spitz-Oener. 2014. "From Sick Man of Europe to Economic Superstar: Germany's Resurgent Economy.” Journal of Economic Perspectives 28(1): 167-88.

— Johannes Ludsteck, and Uta Schönberg. 2009. "Revisiting the German Wage Structure." Quarterly Journal of Economics 124(2): 843-81.

Egger, Hartmut, and Udo Kreickemeier. 2012. "Fairness, Trade, and Inequality." Journal of International Economics 86(2): 184-96.

— Review 64(C): 332-350.

Faggio, Giulia, Kjell G. Salvanes, and John Van Reenen. 2010. "The Evolution of Inequality in Productivity and Wages: Panel Data Evidence.” Industrial and Corporate Change 19(6): 1919-51.

Fairlie, Robert W. 2005. "An Extension of the Blinder-Oaxaca Decomposition Technique to Logit and Probit Models." Journal of Economic \& Social Measurement 30(4): 305-16.

Felbermayr, Gabriel, Giammario Impullitti, and Julien Prat. 2018. "Firm Dynamics and Residual Inequality in Open Economies." Journal of the European Economic Association 16(5): 1476-539.

Firpo, Sergio, Nicole M. Fortin, and Thomas Lemieux. 2009. "Unconditional Quantile Regressions.” Econometrica 77(3): 953-73.

$\longrightarrow,-$, and 2013. "Occupational Tasks and Changes in the Wage Structure." New York, NY: Mimeo.

Fitzenberger, Bernd, Karsten Kohn, and Alexander C. Lembcke. 2013. "Union Density and Varieties of Coverage: The Anatomy of Union Wage Effects in Germany." Industrial \& Labor Relations Review 66(1): 169-97.

— , and Arnim Seidlitz. 2020. "The 2011 Break in the Part-time Indicator and the Evolution of Wage Inequality in Germany.” Journal for Labour Market Research 54: 1.

Fortin, Nicole, Thomas Lemieux, and Sergio Firpo. 2011. "Decomposition Methods in Economics." In Handbook of Labor Economics, Vol. 4, Part B, edited by Orley Ashenfelter and David Card, pp. 1102. Amsterdam, the Netherlands: Elsevier.

Goldschmidt, Deborah, and Johannes F. Schmieder. 2017. "The Rise of Domestic Outsourcing and the Evolution of the German Wage Structure." Quarterly Journal of Economics 132(3): 1165-217.

Håkanson, Christina, Erik Lindqvist, and Jonas Vlachos. 2015. "Firms and Skills: The Evolution of Worker Sorting." Working Paper 2015: 9. Uppsala, Sweden: Institute for Evaluation of Labour Market and Education Policy (IFAU).

Handwerker, Elizabeth Weber, and James R. Spletzer. 2016. "The Role of Establishments and the Concentration of Occupations in Wage Inequality." Research in Labor Economics 43: 167-93.

Helpman, Elhanan, Oleg Itskhoki, and Stephen Redding. 2010. "Inequality and Unemployment in a Global Economy." Econometrica 78(4): 1239-83.

,$- \ldots$, Marc-Andreas Muendler, and Stephen J. Redding. 2017. "Trade and Inequality: From Theory to Estimation." Review of Economic Studies 84(1): 357-405.

Hirsch, Boris, and Steffen Müller.2018. "Firm Wage Premia, Industrial Relations, and Rent Sharing in Germany." IZA Discussion Paper No. 11309. Bonn, Germany: Institute of Labor Economics.

Klosterhuber, Wolfram, Patrick Lehnert, and Stefan Seth. 2016. "Linked Employer-Employee Data from the IAB: LIAB Cross-sectional Model 2 1993-2014 (LIABQM2 9314).” FDZ-Datenreport 05/2016 (en). Nuremberg, Germany: Research Data Centre. 


\section{2 / Daniel Baumgarten, Gabriel Felbermayr, and Sybille Lehwald}

Lemieux, Thomas. 2006. "Increasing Residual Wage Inequality: Composition Effects, Noisy Data or Rising Demand for Skill?" American Economic Review 96(3): 461-98.

Machado, José A. F., and José Mata. 2005. "Counterfactual Decomposition of Changes in Wage Distributions Using Quantile Regression.” Journal of Applied Econometrics 20(4): 445-65.

Melly, Blaise. 2005. "Decomposition of Differences in Distribution Using Quantile Regression." Labour Economics 12(4): 577-90.

Möller, Joachim. 2016. "Lohnungleichheit - Gibt es eine Trendwende?" Wirtschaftsdienst 96(1): 38-44.

Mueller, Holger M, Paige P Ouimet, and Elena Simintzi. 2017. "Wage Inequality and Firm Growth." American Economic Review 107(5): 379-83.

Oaxaca, Ronald. 1973. "Male-Female Wage Differentials in Urban Labor Markets." International Economic Review 14(3): 693-709.

Shorrocks, Anthony F. 1980. "The Class of Additively Decomposable Inequality Measures." Econometrica 48(3): 613-25.

Song, Jae, David J. Price, Fatih Guvenen, Nicholas Bloom, and Till von Wachter. 2019. "Firming Up Inequality." Quarterly Journal of Economics 134(1): 1-50. 